Portland State University

PDXScholar

5-25-1995

\title{
In Search of Roots: A Study of Camus' Autobiographical Le Premier Homme
}

Judy Ann Davis

Portland State University

Follow this and additional works at: https://pdxscholar.library.pdx.edu/open_access_etds

Part of the French and Francophone Language and Literature Commons Let us know how access to this document benefits you.

\section{Recommended Citation}

Davis, Judy Ann, "In Search of Roots: A Study of Camus' Autobiographical Le Premier Homme" (1995). Dissertations and Theses. Paper 4885.

https://doi.org/10.15760/etd.6761

This Thesis is brought to you for free and open access. It has been accepted for inclusion in Dissertations and Theses by an authorized administrator of PDXScholar. Please contact us if we can make this document more accessible: pdxscholar@pdx.edu. 
The abstract and thesis of Judy Ann Davis for the Master of Arts in French were presented May 25, 1995 and accepted by the thesis committee and the department.

COMMITTEE APPPROVALS:

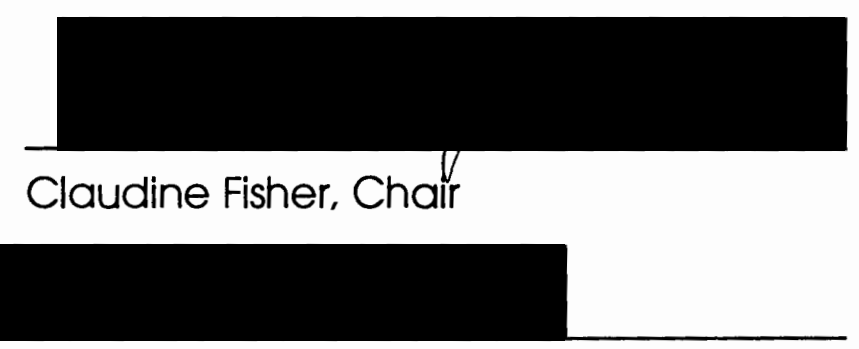

Rita Rose Vistica

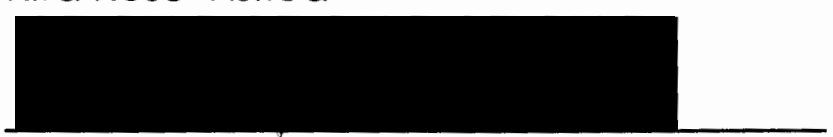

Eric Swenson

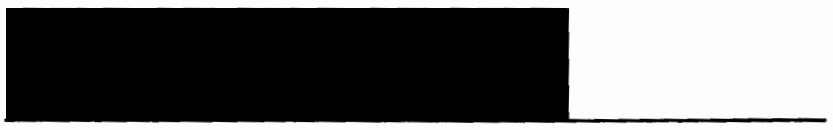

Thomas Luckett

Representative of the Office of Graduate Studies

DEPARTMENT APPROVAL:

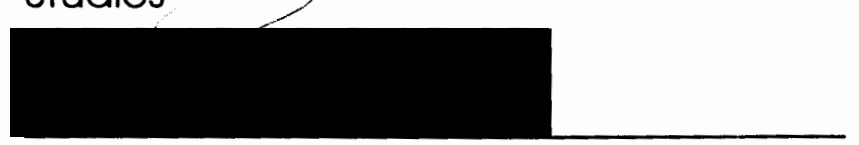

Linda Parshall, Chair

Department of Foreign Languages and Literatures

ACCEPTED FOR PORTLAND STATE UNIVERSITY BY THE LIBRARY
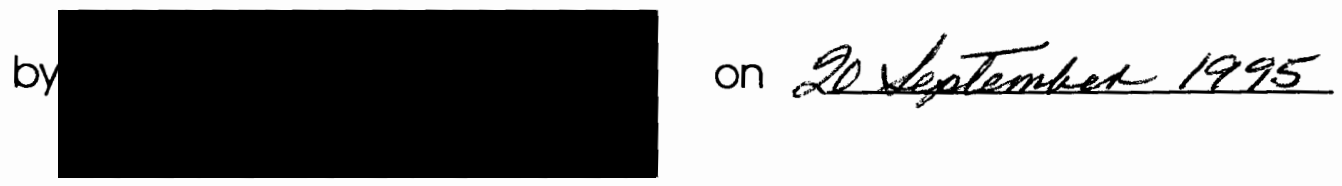


\section{ABSTRACT}

An abstract of the thesis of Judy Ann Davis for the Master of Arts in French presented May 25, 1995.

Title: In Search of Roots: A Study of Camus' Autobiographical Le Premier Homme

Albert Camus' posthumously published novel, Le Premier Homme, shows a new facet of this great twentieth-century writer's art. Intensely personal, the novel speaks of the coming of age of a "pied-noir" (French Algerian) boy and his search for roots as an adult. Simultaneously, Camus endeavors to tell the story of his ancestors, the French Algerians.

The purpose of this thesis is to examine protagonist Jacques Cormery's search for roots by: 1) discussing the formative elements of his identity uncovered in the nostalgic voyage in time through an anecdotal construction of his childhood and the history of his ancestors, 2) linking recurring themes to selected works which will include: L'Envers et l'endroit, L'Etranger, La Peste, and L'Exil et le Royaume, emphasizing the prevalent intertextual allusions, and 3) drawing parallels between the text and Camus' biography, and his artistic and philosophical vision.

First, I demonstrate how themes common to Le Premier Homme and Camus' previous work are interwoven. Throughout the body of his work one finds images of poverty as well as the themes of silence, "strangers/outsiders", the mother/son relationship and communion with nature. 
I identify and analyze the primary influences in the formation of Camus' "first" (or original) man. These include: the father (as forgotten and enigmatic), the surrogate fathers whom Jacques finds in the uncle and the teacher, and the grandmother. Additonally, I establish the autobiographical underpinnings of Camus' thinly veiled protagonist, Jacques Cormery, by comparing the story in the novel with Camus' biography.

A discussion of style deals with influences and the writer's narrative technique. Examples of his use of ambiguity, paradox, and irony are cited in addition to some of the unique imagery.

Finally, I demonstrate that this vivid resuscitation of Jacques Cormery's childhood world as autobiography reflects some of the sources of Albert Camus' vision. The novel underscores the lessons of poverty, Camus' admiration for the poor working class "pied-noirs" who live in the present, Sisyphean models, and the notion of ambiguity. 
IN SEARCH OF ROOTS:

\section{A STUDY OF CAMUS' AUTOBIOGRAPHICAL \\ LEPREMIER HOMME}

\section{by}

JUDY ANN DAVIS

A thesis submitted in partial fulfillment of the requirements for the degree of

MASTER OF ARTS

in

FRENCH

Portland State University

1995 


\section{TABLE OF CONTENTS}

ACKNOWLEDGEMENTS.

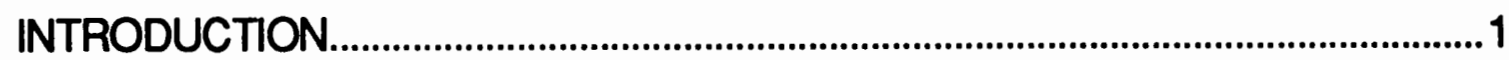

\section{CHAPTER}

THEMATIC MOVEMENTS ...........................................................................4

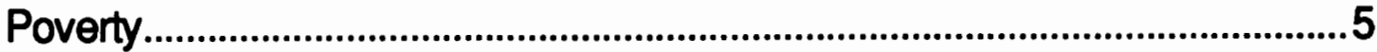

Silence ..............................................................................................12

The "Stranger/Outsider" Developed in Previous Works..............15

The "Stranger/Outsider" Developed in Le Premier Homme .........24

The Arabs as Strangers ............................................................................. 28

Mother/Son Relationship........................................................................... 33

Nature ..................................................................................................... 40

II PRIMARY INFLUENCES ON THE FORMATION OF

CAMUS' "PREMIER HOMME".....................................................................50

The Father........................................................................................... 50

Surrogate Fathers: Uncle Etienne/Ernest and

Monsieur Bernard.........................................................................................53

The Grandmother....................................................................................59

Jacques' Childhood Friends: Pierre Marlon and

Georges Didier ............................................................................................... 64

III AUTOBIOGRAPHY IN LEPREMIERHOMME ……...................................70

IV STYLE ............................................................................................ 81

V CAMUS' VISION REFLECTED IN LE PREMIER HOMME..........................90

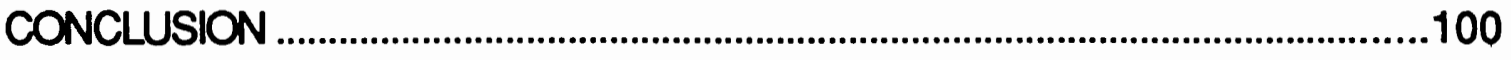

WORKS CONSULTED........................................................................................104

APPENDICES

A CHRONOLOGY

B ABBREVIATIONS USED FOR CAMUS' WORKS IN THIS THESIS 


\section{ACKNOWLEDEMENTS}

I want to offer my sincere thanks to Professor Claudine Fisher for her encouragement, guidance, patience, and positiveness. Her energy and enthusiasm are inspiring. Professor Fisher's knowledge and understanding of the "pied-noir" culture have been especially beneficial to me in studying this text. It was through her guidance that I made my way to and through Le Premier Homme.

I will be forever grateful to Professor Rita Rose Vistica who was the first to really introduce me to the large body of Camus' work and to instill in me a deep appreciation for this writer. Her thoughtful suggestions and meticulous reading of my work were invaluable.

Heartfelt thanks go also to my husband, Patrick, whose generosity, humour and rallying spirit kept me going on this project. Patrick's appreciation of Camus and his interest in my paper was a gift. I'm also grateful for the time he offered to help me proofread.

Finally, I want to thank my friends for their encouragement, and especially my friend and colleague, Rhonda Severn, for all her moral support. 


\section{INTRODUCTION}

Within the span of his short life of forty-six years, the legendary French Algerian writer, Albert Camus, produced a notable body of novels, plays, essays, and articles and also won the Nobel Prize for Literature in 1957. Camus defined and shaped a vision of the twentieth century, a vision that he claimed he owed to his humble background and his birthplace, Algeria. In his Nobel Prize address in Stockholm, he eulogized the sunlight, the delight in life, and the freedom in which he grew up. He said that through the nostalgia for his childhood he had learned his calling and his ability to find solidarity with the poor and oppressed men and women for whom he wished to speak.

From his first essays to his last published work, a collection of short stories, and from many of the plays and novels in between, echos of Camus' Algeria can be heard. The landscape, with its sun, sea, desert and stone, the working class neighborhood of Camus' youth, Belcourt, the men and women, models of Sisyphus, the strangers and the exiles---all are familar motifs in his work.

Thirty-four years after his death, Camus' daughter Catherine gave permission to publish the manuscript of Le Premier Homme, an autobiographical novel that her father had been writing when he died. The work is compelling not only because it gives insight into the psychological and social formation of a working-class "piednoir" boy but also because it is a journey of self-discovery that 
reveals more of the hidden, very private Camus. No doubt had the novel been completed, the thinly-veiled protagonist, Jacques Cormery, would have been further disguised but the existing text contains biographical similarities that are remarkable. This biographical material provides insight into the development of Camus' unique vision and reaffirms some of the assumptions made by biographers and critics. It is also an attempt to tell the story of French Algeria at the moment in history when its very existence was being threatened. The writer holds true to his conviction stated in the Nobel Prize acceptance address for he continues in this work to speak for those on whom poverty had imposed silence; this time he speaks for his family and in his voice we hear his gratitude and love.

Camus viewed his art as the body of his entire work, not just isolated writings. It is in this vein that the reader will approach $L_{\theta}$ Premier Homme to see that it develops the images in his early work, L'Envers et l'endroit, by filling them in with a myriad of Balzacian details. Characteristic of previous writing, Le Premier Homme bears the mark of Camus' Algerian birth, his celebration of the physical life, human warmth and compassion, as well as suffering in the face of separation and loneliness.

According to his biographer, Herbert R. Lottman, the novel was initially to be called Adam, an obvious reference to the biblical first man whose name literally means "every man". In one sense, the ambiguous title refers not only to Jacques Cormery's absent father as a first generation Algerian, but also to Jacques (Albert Camus) 
"growing up in a cultural and historical vacuum accentuated by his family's illiteracy" (Lottman 31). Additionally, Jacques comes to see his connection to the other working-class "pied-noirs" (those French who were born in Algeria) and those who initially settled there, other "first men" who are outcasts, exiled from France and strangers in Algeria. Their legacy, like that of the "first family" is a kind of rupture with nature and the killing of other men. As a modern day Adam, Jacques seeks knowledge -..- what he might have known from his father to become a whole integrated person.

Camus' story is comprised of anecdotes and admirable portraits of the beloved Mediterranean of his youth. As he reconstructs a poignant childhood, one recognizes his art and the components of his vision in this novel that differs from much of his writing in its personal, confessional tone and its traditional form.

The reader has only a glimpse of the adult protagonist, a man torn by ambivalence and contradictions whose mission is to discover his long forgotten dead father. We follow Jacques Cormery's journey into the past, a journey of self-discovery that eventually leads to resolution. 


\section{CHAPTER I}

\section{THEMATIC MOVEMENTS}

In the Preface of the 1957 edition of L'Envers et l'endroit, Camus tells his readers that if he doesn't succeed in rewriting these tales from his youth, he will not have succeeded in anything. He speaks of a future work: "elle parlera d'une certaine forme d'amour." Imagining a work in which " l'admirable silence d'une mère et l'effort d'un homme pour retrouver une justice ou un amour qui équilibre ce silence", he set about writing Le Premier Homme. At this point in his career, the 44-year-old writer who had lived through war and moral dilemmas of his time, who had loved and created, came to the conclusion that often an artist's work is ultimately a long road to the discovery of the two or three simple, yet great images that had made an initial impression on one's consciousness (EE 29). Thus, just as the middle-aged Jacques Cormery comes to seek his roots, so the writer Albert Camus looks back to his own origins reflected in the essays of his youth. Certain images from this early text reccur throughout the body of Camus' work and can be traced in the posthumous Le Premier Homme which takes him full circle back to some of his preoccupations as a young writer. Themes of poverty, silence, filial love, fraternal love, the "stranger/outsider", and communion with nature are theme and substance of this last unfinished novel. 
Poverty

Camus states in the preface of L'Envers et l'endroit that living in poverty as a child was never a misfortune as he had lived in a sunny, warm climate:

...je fus placé à mi-distance de la misère et du soleil. La misère m'empêche de croire que tout est bien sous le soleil et dans l'histoire; le soleil m'apprit que l'histoire n'est pas tout (EE 14).

While bathed in the light of the Algerian sun, Camus claims that he was able to recognize the riches that surrounded him. At any rate, he considers this a privileged position. He further explains that the warmth of his childhood kept him from resentment (a danger, he claims, that threatens the artist) and although he lived in deprived circumstances, he experienced great enjoyment. Poverty was not an obstacle; he drew strength from the natural riches of his Algerian world---a land where the sun and sea had no price tag (EE 13-14). Yet, it is with characteristic ambivalence that the writer frames his account of Jacques Cormery's childhood in Belcourt.

Clearly, Camus sees both sides of poverty, "l'envers et l'endroit". Despite all of its associations with want, misery and ignorance, poverty has its own irreplacable riches. The young Jacques Cormery must sacrifice his most valuable possessions, the summer sky and the sea, to take a summer job at the age of 14 in order to contribute to the household (LPH 251). The domain of the poor as seen through Jacques' eyes is "royal", full of "richesses irremplaçables" and 
"trésors". In the jubilant moments while at play in the school yard, he feels like "le roi de la cour et de la vie".

Several times in the text, the writer uses the paradox "pauvrete chaleureuse" to refer to a source of his strength and sense of fraternity. At the same time, the text underlines the paradox of Jacques' childhood among the poor with numerous negative commentaries. From Jacques' perspective (colored by his exuberance for living), his mother, his friends, the beach, and the hot afternoons spent playing endlessly all constitute the "joys" of his childhood.

However, the under side of his experience of poverty is examined as well. In various anecdotes, the boy's shame is related. For example, his clothing is bought over-sized to guarantee that he gets lots of wear from it and he is forbidden to play soccer (although he does so anyway) to save the soles of his shoes which have been protected by tacks driven into them, thus elevating them from the ground. Another sort of shame surfaces when Jacques keeps the change after buying some food for the family. He concocts a story to cover his holding on to two francs change and is horrified when his grandmother verifies his alibi by fishing in vain for the coin in the toilet with her bare hands. At that moment, Jacques realizes that she is not motivated by greed but does this out of necessity. Indeed, two francs was considered a sum. His shame is born from his having profited from the work of the other family members. 
His grandmother's appearance and comportment are a further source of shame for Jacques. When she attends the end of the school year ceremony to honor the high achieving students, she wears the traditional Spanish black dress and scarf as a head covering. As a poor woman, she never leaves Belcourt so this special occasion is quite an event in her life and she does not stop commenting to her neighbors throughout the ceremony, much to his chagrin.

When Jacques enters high school, he feels for the first time a new kind of shame when he must indicate his mother's profession as "domestique". Confronted for the first time with bourgeois values, this shame comes from a sense that he will be judged and not from his own sense of self-worth. Camus explains " un enfant n'est rien par lui-même, ce sont ces parents qui le représentent. C'est par eux qu'il se définit, qu'il est défini aux yeux du monde." (LPH 187)

This judgement comes without an appeal. If in fact at a young age a sensitivity to the judgements of society is developing in Jacques Cormery (who represents Camus), one can imagine the first seeds of the writer Camus' problems with judgement and sentencing taking root.

Only when Jacques brings home his first pay does he feel empowered by helping to reduce the family's misery; his shame is transformed into pride. By contributing financially, he is initiated into manhood, crossing the threshhold of independence but with a price. Previously, Jacques had spent his summers roaming the streets, playing and swimming with friends---rain or shine.Those days come to an end when he is forced to assume the responsibility 
of work. His sacrifice of " les richesses et les joies de la pauvretén" for the curse of long monotonous hours, heat, boredom and fatigue is painful. Jacques concludes ironically that the interminable monotony served to "rendre en même temps les jours trop longs et la vie trop courte" (LPH 248).

For two summers, the boy is obliged to work denying himself the priceless freedom of long summer days. The pleasure of being outdoors is sacrificed in the first job for the dark, metallic smelling office where as soon as he entered, he sensed its effect on his spirit: "une lumière s'éteignait en lui, le ciel avait disparu" (LPH 244).

Camus associates a kind of ignorance, a naiveté, with the poor. For example, restaurants are "bewitched" places where clients are seduced by the deceiving ease in which they can procure a number of culinary delights, only to pay dearly with both purse and stomach. The ignorance of Uncle Etienne/ Ernest, another victim of poverty, demonstrates a precarious sense of honor (which to the contemporary reader may seem distorted) when he chases away Jacques' mother's suitor. Although Jacques held a grudge as a child, he does not completely condemn his uncle for he sees Etienne/ Ernest as a product of infirmity and need. The reader is also reminded that due to the strong Spanish influence in this matriarchal home, this sort of anecdote stresses the insulation of Jacques' community for the uncle was no doubt responding to Spanish norms of the time. 
Looking back, Jacques is struck by other attitudes of the poor: their humility and their guilt. He remembers his family always arriving early to the school's honor ceremonies because as a poor family, they had no other social obligations and especially because they felt responsible; "...ils sentent qu'il ne faut pas ajouter à cette culpabilité générale par des petits manquements" (LPH 231).

In this depiction of the world of the poor child, the narrator underlines the contrast with that of other children; in the Cormery household, there were no books, newspapers, or radios, and all of the adults in the family were illiterate. Jacques is forced to read the subtitles of the silent films for his grandmother. We learn that his mother has no sense of her own history (she is immersed in a French dominated society where she is cut off from her Spanish roots) much less the history of France or Algeria. When Jacques asks his mother: "Maman, qu'est-ce que c'est la patrie?" she looks afraid because she doesn't understand. Jacques provides the rote response that has no meaning for either of them. Camus uses a metaphor that captures the impregnability of this world of poverty and ignorance: "La misère est une fortresse sans pont-levis" (LPH 138).

Yet amidst the hardship Camus presents a portrait of a proud family. In spite of the fact that Jacques' mother works for other families, she always is sure that her children are dressed in clean, pressed clothing. So neat are the Cormery children that the schoolteacher, Monsieur Bernard, who taught both Jacques and his brother, only discovers the extent of their privation when he comes to their apartment. 
The adult Jacques' efforts to penetrate the mystery and anonymity surrounding his father reveals that it is ultimately the family's poverty that accounts for the mystery of the father. Poverty engenders beings without names or pasts: "... l'anonymat au niveau du sang, du courage, du travail, de l'instinct à la fois cruel et compatissant " (LPH 180). The father's station in life as an immigrant orphan with no connections with the past and his childlike widow (who had come to forget him) as the only witness to his existence rendered him unreachable and anonymous. This was the fate of the poor who had come from Europe; in the battle to survive, connections and continuity with the past were destroyed. And although, Jacques himself had tried to escape the anonymity of "la vie pauvre, ignorante, obstinée", "...cette patience aveugle, sans phrases, sans autre projet que l'immédiat" (LPH 181-2), it was part of him and had in the end helped him face the world and the particular circumstances of his time. Mature Jacques focuses on his roots and yet must recognize that he was in some way a part of another world across the sea:

La Méditerranée séparait en moi deux univers, l'un où dans des espaces mesurés les souvenirs et les noms étaient conservés, l'autre où le vent de sable effaçait les traces des hommes sur de grands espaces (LPH 181-2). [Note the use of the first-person pronoun "moi" it is one of the few slips in the text that reveal the author's identification with Jacques.]

In recognizing Jacques' links to the poor of Belcourt, Camus examines and defends the xenophobia among the working class "pieds noirs". He calls them "les plus tolérants des hommes" but when it 
came to the question of work, they considered everyone guilty of stealing it. The Italians, the Spanish, the Jews, and the Arabs were all perpetrators. Though disconcerting for him, Camus finds this attitude very human and excusable. They were in fact, he contends, disputing their privilege of "servitude"; work in Belcourt was not "une vertu mais une nécessité" (LPH 237).

Camus' depiction of poverty and its consequences for this family is quite effective. Children in his work are scarce but in Le Premier Homme, he is successful in creating a child's perspective as the adult Jacques makes nostalgic forays into his childhood. The author is clearly elevating the richness of his experience, however contemporary readers may tend to see the boy as a victim. Despite the dark side of his situation, his contentment and experience of love prevented him from desiring another kind of life.

Avec tout cela, Jacques ne désirait nullement changer d'état ni de famille, et sa mère telle qu'elle était demeurait ce qu'il aimait le plus au monde, même s'il l'aimait désespérément. Comment faire comprendre d'ailleurs qu'un enfant pauvre puisse avoir parfois honte sans jamais rien envier? (LPH 188)

From the shame and sense of compassion he felt to the joys of the eternal summer such as the invented games played with rag balls, the gourmandise of a solitary French fried potato shared on a beach, joys oblivious to the silence of a worn-out mother, Jacques' childhood is laid out. Hence, the reader comes to know a boy full of life, born into hardship but soothed and caressed by the sun and sea. 


\section{Silence}

In addition to financial hardship and social disadvantage, Jacques suffered from an emotional poverty in the silence of both his mother, Catherine Cormery, and the whole family. Living with two partially deaf adults (his uncle and his mother), both ruled by a grandmother who appears to us as tyrannical, interaction was minimal. When his uncle spoke, the utterance was generally composed of sound effects and brief phrases while his mother rarely spoke. Her words were neutral, gentle or encouraging and generally associated with her pride in Jacques' academic successes. "Tu as bien travaillé" is the extent of her acknowlegement (LPH 235).

Camus' implicit explanation of this curious lack of communication emerges in a portrait of a young woman completely dominated by her mother and her poverty, exhausted by the drudgery and physical demands of her work as a maid. Youthful and handicapped, Catherine is treated as a child and is consequently as powerless as Jacques. Thus, the reader is given some insight into this character and her reticence to speak. Catherine Cormery never expresses verbally her love for her son, though Jacques perpetually longs for this. Her silence begins to take on a special significance as Jacques imagines a certain communication of their love; this is a kind of pact in the oppressive home. After a day of domestic work, Catherine sits in the same place, staring out the window, watching passers-by, rarely interacting with the family. Her son, confronted with physical and emotional distancing, dares not approach her. 
A few details evoke the pain of her life: the piece of shrapnel that killed her husband, two cards written by him from the hospital where he died, the barren rooms of the apartment. For the narrator, her indifference is the badge of suffering, lived in silence. This silent mother re-emerges as the same one portrayed in "Entre oui et non". Lost in silence, staring fixedly, the latter also sits at the window. The strange inexplicable silence of the mothers in both works affects the sons similarly. Both experience an anxiousness, a dull pain, and finally solitude. "... il a peur. II commence à sentir beaucoup de choses devant ce silence animal" (EE 61). "... pendant que son fils inlassablement, la gorge serrée, l'observait dans l'ombre...plein d'une angoisse obscure devant un malheur qu'il ne pouvait pas comprendre" (LPH 209). (A further discussion of the significance of the mother is taken up in the section dealing with the mother/son relationship.) The lessons learned from this enviroment of poverty and silence parallel what Camus the writer claims to have enriched him: "...une certaine fidelité... et la tenacité muette" (EE 20).

In their book, Silence dans l'oeuvre d'Albert Camus, Hiroshi and Viallaneix point out that silence is often imposed on Camusian characters. They maintain that Camus learned about silence from his mother and from nature; silence envelopes both creation and love. This silence becomes integral because it communicates; it comes close to Rousseau's "communication immédiate " where smiles and looks take precedence over words that can confuse or unbalance a situation (Hiroshi/Viallaneix 20). 
The gulf of silence between Jacques and his family widens when he enters high school. They cannot fathom academic life; there is little to say, little that they can understand, no real point of reference. They especially cannot relate to Jacques' passion for reading. Books are mysterious things to his mother who tries to grasp the power that they have over her son. Because she cannot read, she relies on her senses to uncover this mystery; she smells and touches the books that Jacques brings home from the library (LPH 229).

While he is transported by his reading, physical activity provides Jacques with an outlet to express his exuberance for life. Soccer at school and street games connect him with friends with whom communication seems much easier. 
The "Stranger/Outsider" Developed

in Previous Works

Being French Algerian, Camus develops the theme of the "stranger/outsider" from a unique perspective. Ordinary characters in a North African world reflect dilemmas of existence that are universal. Arabs, though they play roles in his work that suggest partial alienation, should be understood to be products of the historical moment and of their state as colonized people.

The French "strangers/outsiders" striken by their existence often have the experience of a moment of lucidity that binds them to another (or others), or to the universe. At a certain moment, characters, "strangers" to themselves, surpass their ordinary lives and the pain of their existence because they discover either a capacity to attain a certain harmony with the universe or to experience a moment of fraternity. The notion of "stranger/ outsider" is frequently treated on several levels in a number of Camus' texts. A careful look at Meursault in L'Etranger (the great Camusian "stranger/outsider"), Rambert in La Peste, several protagonists in L'Exil et le royaume, Jacques Comery and some of the minor characters in Le Premier Homme, as well as the few Arabs that inhabit the background in certain texts, reveals "l'envers et l'endroit" of the "stranger/outsider": hope and fraternal love, and the alienation and difficult choices human beings face. In this section a careful examination of this important Camusian theme will establish its signifigance and draw parallels between previous 
texts and Le Premier Hemme. First, I will discuss the notion of "stranger/outsider" in earlier works and then analyze its development in Le Premier Homme.

From the beginning of the story, Meursault, the protagonist in L'Etranger is presented as "stranger/outsider". His apparent indifference at his mother's burial signals to the reader that the character is original (and yet paradoxically quite average) and perhaps outside the realm of what one would call normal. Portrayed as a robotic character, Meursault recounts quite dispassionately, the events of his ordinary world. In his case, his comportment calls into question the rules of society; he refuses to play the game and eventually society seeks to eliminate him.

For all of the "serious" considerations of life (social advancement, marriage, the death of a parent), Meursault shows an indifference that opposes established societal values. Society requires its members to have a certain ambition, take marriage seriously, and publicly mourn the death of a relative. Meursault's inability to articulate his experience and defend himself cannot be tolerated. His world is small; it is geographically limited to his neighborhood, limited to a small group of acquaintances. The life he leads can be reduced to the most simple activities and adheres to reality in a quasi-animalistic fashion. He is not at all a stranger to his body as the physical aspect of his universe is quite evident. He responds to his physical needs: if he is hungry, he eats, if he is thirsty, he drinks, and if he is drowsy, he sleeps. If it is a question of a cigarette or a woman, he will have them. All of his activity is 
itself an end. He does not exist to work; he works to exist. As the post-Camus era saying goes, "Métro, boulot, dodo", the banal routine of the life he shares with a few people in his neighborhood, creates a universe where Meursault is not stranger.

In addition, the two other bachelors, his neighbors, live in one room, just as he does. Meursault unconsciously identifies with Salamano who lives with his dog and then loses him just as Meursault has lost his mother. Although his relationships are superficial, the fact that Meursault names his friends, establishes the fact that there is a world to which he belongs. Among the various characters, only his friends (and his mother's friend Pérez) are named.

Meursault is, however, a "stranger" to himself. Meursault can only exist in the present as his orientation to the physical does not admit a past or future. He explains to his lawyer that he has a nature such that physical needs often interfered with his feelings (ETR 102). But Meursault does not see himself alienated from others: "...j'étais comme tout le monde absolument comme tout le monde" (ETR 103). During the interview for the trial, he has the impression of being accepted. First, in prison, he does not recognize his own image reflected in his tin plate nor is his own voice familiar to him. However little by little, he becomes aware of his past which leads him to become aware of his life and even desire a future. The first affirmation of this "prise de conscience" takes place during the trial when his lawyer was speaking. 
...la trompette d'un marchand de glace a résonné jusqu'à moi.

J'ai été assailli des souvenirs d'une vie qui ne m'apppartenait, mais j'avais trouvé les plus pauvres et les plus tenaces de mes joies: des odeurs d'été, le quartier que j'aimais, un certain ciel du soir: le rire et les robes de Marie (ETR 160-1).

Later from his jail cell, he gains a new awareness of the natural world and is flooded with a sense of peace: "Des odeurs de nuit, de terre, et de sel rafraîchissaient mes tempes. La merveilleuse paix de cet été endormi entrait en moi comme une marée " (ETR 185). Formerly alienated, Meursault opens up to "la tendre indifférence du monde" and in that place experiences a fraternal bond in which he recognizes his happiness.

The image of the stranger in the allegory, La Peste, is given shape in Raymond Rambert, a journalist who comes to Oran to report on the living conditions of the Arabs. Ironically, Rambert, seeking information for this article falls on another story (the beginning of an epidemic) which may be a story equal to his intended one. He cannot, however, appreciate this opportunity because he is literally imprisoned by this drama.

Unable to leave, Rambert initially despairs at the injustice and tragedy of his particular situation. He is only "un étranger à cette ville": "...je ne suis pas d'icil" (P 84) As an outsider, he cannot see any connection he might have with the crisis; he is not from Oran and he does not have the disease. This denial reinforces his status as "stranger/outsider". At the same time he continues to maintain his "stranger/outsider" role by not fighting against the plague. 
Motivated by the pain of separation from someone he loves, Rambert, one of "les plus exilés" finally acts. Rambert remains on the outskirts of the crisis; his focus is escape which keeps his attention on the "outside" and particularly on the city's gates. The obsession to leave and refusal to see himself linked to the people of Oran drives him to deal with Cottard, the smuggler. This act has the potential of further alienating him but he finally chooses to stay rather than suffer from the shame of being "heureux tout seul". Thus, he finally values solidarity and takes responsibility for others. Because he is where he is, he is involved whether he wishes to be or not.

J'ai toujours pensé que j'étais étranger à cette ville et que je n'avais rien à faire avec vous. Mais maintenant que j'ai vu $c \theta$ que j'ai vu, je sais que je suis d'ici, que je la veuille ou non. Cette histoire nous en concerne tous ( $P$ 190).

This new consciousness supports his choice to stay and generates the courage to make the effort to love and give of himself. He is then willing to sacrifice his personal happiness to act out of his sense of solidarity. Additionally, the shift of his focus from moving "outside" away from the crisis results in a movement "inside" towards others.

In the beginning of "L'Hôte", from L'Exil et le rovaume, Daru, the French school teacher feels exiled everywhere but in this harsh "pays de pierre", "cruel à vivre", however his origins render him a "stranger/outsider" to the indigenous population. The fact that he is the only French person to live in that isolated place accentuates his 
solitude. He lives far from the sea (which provides an opening to the outside world) on a plateau (which symbolically separates and raises him up) in a school (symbol of colonisation). Because the school serves as a food distribution center, Daru as representative of the administration, holds power that separates him further from the Arabs. This is subtle but its impact is significant; representing the "colonizers" (although he may not see himself as superior), he alienates himself and perpetuates the alienation of those he wishes to serve.

Camus underlines the austerity of the land with its forbidding climate and vastness, where any person might seem out of place. Nature keeps Daru in extreme isolation regardless of his desire to be welcomed. When faced with the existential dilemma of delivering the Arab prisoner, Daru adds to his estrangement; by refusing to fully cooperate with the French authorities and then by allowing the Arab to choose his own destiny, he is condemned by both sides and belongs nowhere. Daru, like Meursault, does not accept the game and the consequences are serious.

Daru's attitude towards the Arab prisoner encourages a level of fraternity. He neither judges nor condemns, nor does he accept the responsibility for the other's future (although he does not accept the Arab's crime). He treats the Arab with humanity as he would anyone by untying his bonds, sharing a meal, providing a bed, and finally his liberty. The unique brotherhood, imposed in a sense by the circumstances, signals that the conditions of the Camusian "étranger" are not static. The brief moments of fraternity are 
temporary; in the end the message left on the blackboard indicates to the reader that Daru remains a "stranger/outsider", innocent but found guilty. Having been so judged, Daru, the "outsider" cannot be accepted as an "insider".

D'Arrast, in "La Pierre qui pousse", like Daru goes to live among indigenous people. Exiled from France, he is the benevolent stranger, offering his services as an engineer, who goes to live in a Brazilian village. On a physical level, d'Arrast is conscious of his enormous size and feels weighted down. His imposing stature is a metaphor for his origins---the presumably superior European culture that he is rejecting in his exile. He is neither at ease among the elite "colons" who host him nor among the poor indigenous people for whom he has sympathy.

Showalter compares him to Daru in that he rejects a part of his European roots and most institutions in his culture, and like Daru, he is not accepted elsewhere (89). Consequently, d'Arrast remains a "stranger/outsider" until the moment when he makes the effort to act out of his fraternal love on behalf of another by carrying the stone.

His kindness towards the native people indicates the desire to be accepted and to escape his status as "stranger/outsider". In the beginning he is not welcomed because he is too much of an "outsider" and is unable to communicate and thus establish any real ties. Nevertheless, d'Arrast takes the first step to become less apart by entering one of the huts. As he becomes more accepted, he is invited 
to participate in a celebration, but he is unable to integrate himself into the festivities and in the end is excluded.

Only later all barriers seem to be destroyed when D'Arrast reacts out of instinctive compassion and carries the stone for the cook. Tarrow maintains that this act of descending from his position on the balcony where he is a superior "stranger/outsider" and entering the street procession to help an individual influences the whole community (Tarrow 82). Fraternal love directs his actions.

By placing the stone in the family's hut, he demonstrates the solidarity that as a "stranger/outsider" he wants to prove. Again, a single moment of love transforms him, lifts him out of exile and makes him sit with this poor family who had formerly greeted him with resentment.

Janine, in "La Femme adultère", one of the rare developed female characters in Camus' writing, is a stranger to herself---both her past self and her present. From the outset of her journey by bus (her husband's sales trip), she becomes aware of her size; she would like to take up less space on the seat in the bus. A middle-aged woman now, she is alienated from her former self, a fit gymnast who did not know what it meant to be winded. In the bus, her body does not seem to be her own and she feels further estranged by the fact that she is the only European woman. Even her sense of time is confused; her youth of twenty-five years ago, though far from the life she is leading now seems like yesterday whereas the bus trip they began that morning seems to Janine to have lasted for days. The sun, sea, 
beaches and even the sky of her youth are foreign to her now. Life has suddenly gone by and Janine is so estranged from herself that she cannot connect the person she was to the person whom she has become.

In the present, she finds herself in a cold stony desert where she is not at all at ease. The fog appears to be a hostile force that flings sand against the windows of the bus and eventually in her face. Showalter, drawing a parallel with the New Testament story, points out that stone represents a harsh inflexible reality here as it did in the Gospels (Showalter 27). It is this reality that Janine is coming to terms with as the story progresses.

As the trip advances, Janine continues to focus on her heaviness and her ability to attract men. After the soldier in the bus offers her a lozenge (which might be signalling an overture), he ignores her. This attitude mirrors that of her husband as well as that of the many men passing in the street who fail to take notice of her. This estrangement from the men augments Janine's uneasiness.

The malaise and undercurrent of Janine's alienated sexuality is evoked by erotic imagery throughout the text. After visiting the fort, Janine reflects on her sexuality. She understands that she and Marcel are together out of need, out of a desire to avoid their own solitude and inevitable death.

Janine's first epiphany occurs at the fort when she notices the nomads in the distance. She cannot readily understand the signs that the desert is communicating. As she gazes at the surrounding desert and the horizon, Janine gets a taste of the mystery that lies 
there. Indeed, she is an outsider to the kingdom of the poor yet free nomads who appear to be engraved in the landscape. This sense of additional estrangement creates yearning that wells up inside her. Compelled to return to the fort alone that night to satisfy her longing, Janine experiences a metaphysical union with the night sky. This crucial moment of offering herself up allows her to join with the natural world and thus allows her "to rejoin" herself, rediscover herself.

\section{The "Stranger/Outsider" Theme Developed in Le Premier Homme}

Jacques Cormery also bears some of the marks of the typical Camusian "stranger". The circumstances of his birth situate him at the beginning of his life in a remote place, far from civilisation where he is born on a cold, rainy, autumn night in obscurity. The parallel with Christ's birth narrative is noteworthy: the humble parents, the journey to a new place, and the stark setting among foreigners. Even the initials of his name indicate the Christ connection.

As a young boy, he first encounters the feeling of being a stranger in the presence of his mother. She seems to inhabit another world that Jacques cannot penetrate. We detect a mirroring of the character in "Entre oui et non" as Jacques watches his mother sitting in silence at the window. Both characters want to reach out, break the silence, and finally win an unspoken love. The mothers' 
indifference in both stories fuels the boys' longing and unmet needs for affection (which Jacques succeeds in naming only as an adult). Jacques can be compared to d'Arrast who takes steps towards the villagers in an attempt to connect with them on a human level; the boy makes a tenative initiative to reach out to his mother to end his perceived exile from her interior world. For example, when Catherine Cormery is scorned by her own mother for having cut her hair, she is distraught so Jacques tries to comfort her. Her response is to wave him away (LPH 116).

After earning a scholarship for the "lycée", Jacques is flung into a new universe where he can no longer depend on $M$. Bernard, the primary school teacher who helps him prepare for the entrance exams, much less his isolated, illiterate family. In the critical scene where his beloved teacher comes to bid Jacques farewell, the boy is left surrounded by women and the realization that he was being propelled into a world that was no longer his, a world where he would have to learn and understand without help, where he would have to become a man and grow up alone at a price ("le prix le plus cher"). Success then would estrange him from his "monde chaleureux des pauvres" (LPH 163). Early on Jacques experiences another solitude: the solitude in the outside world. Leaving his familar territory, he would forever be a "stranger/outsider".

His awareness of the singularity of his family (as compared to those of his bourgeois classmates) did not make it any easier to articulate or manage in the context of school. Pierre, Jacques' only friend from Belcourt, might have sensed a similar apartness, but 
this was only implied. Camus describes how the two boys from the other side of Algiers were "outsiders".

Ce n'était même pas la différence des classes qui les isolait. Dans ce pays d'immigration, d'enrichissement rapide et de ruines spectaculaires, les frontières entre les classes étaient moins marquées qu'entre les races. ...Non, ce qui les séparait, et plus encore Jacques que Pierre, parce que cette singularité était plus marquée chez lui que dans la famille de Pierre, c'était l'impossibilité où il était de la rattacher à des valeurs ou des clichés traditionnels" (LPH 186-7).

His friendship with Georges Didier who had come directly from France made Jacques realize that he was a stranger to bourgeois values that obviously dominated that mythical place called France.

The adult Jacques views himself as an outsider in France where he feels distanced from the land that he sees as somehow ailing. The contrast between his facile contact with nature in Algeria and the feeling of imprisonment in "la forêt de ciment et de fer" of the northern French cities reveals an awareness of a deep-rooted alienation (LPH 44).

A mature Jacques also looks back on the history of the Europeans who first came to his beloved Algeria (in 1830 and then in 1871), he identifies his own links to this group of exiles whose suffering takes on biblical proportions. "Outsiders" in a harsh land, their "promised land", they seem to be rejected by nature. Without roofs over their heads or any comforts, they had struggled through deluge, cholera, and a variety of threats from beasts and men. These strangers in a strange land began a cycle that Jacques Cormery had tried to escape: 
Des foules entières étaient venues ici depuis plus d'un siècle, avaient labouré, creusé des sillons, de plus en plus profonds en certains endroits, en certains autres de plus en plus tremblés jusqu'à ce qu'une terre légère les recouvre et la région retournait alors aux végétations sauvages, et ils avaient procréé puis disparu (LPH 178).

Their laboring, digging deeper and deeper, is a metaphor of the colonists attempt to attach to the land. As several generations of these "strangers" live, work and die, and are gradually forgotten, Camus points out that given the present conflict (the ongoing clash of the 1950's between France and the FLN), this particular group risks exile again, and thus, their memory could truly fade into oblivion. (In fact, his prophesy has been realized in contemporary Algeria.)

One minor character, Veillard, a "pied-noir", takes a path that parallels other Camusian "strangers/outsiders" by refusing to leave the land even when his life may be threatened. In his mind, he is as linked to Algeria as the Arabs. He resembles Meursault in his determination to cling to his own truth: that the Arabs are in fact his brothers, "aussi bêtes et brûtes que nous, mais le même sang d'homme", and that the brutality of the conflict will continue but peace will eventually be restored, and finally that he belongs there (LPH 168). According to Veillard, this is the destiny of the land and he will risk losing family, friends and potentially his life just to continue to stay on. His role, as his name suggests, will be to "veiller" or watchover/guard the land developed by his father as well look on as the situation takes its course. Like Daru, Veillard is 
a "stranger / outsider" who has made a difficult choice in line with his conscience, making himself a target for Arab hostility and further alienation.

\section{The Arabs as Strangers}

The treatment of Arabs as strangers in Camus' work reveals a metaphysical exile. Ironically, French Algerians appear at times less alienated than the Arabs, who although linked to the land, remain "strangers/outsiders" to its dominant culture and laws. For example, the Arabs who people L'Etranger, although they are indigenous, are alienated in their own country. The reader encounters them as depersonalized beings on the periphery of the French Algerian world. They are fused to the landscape, almost shadows, and therefore, may lose their status as persons in some readers' minds.

The Arabs we encounter in L'Etranger are without faces, personalites and distinct identities. Part of a menacing background, they follow the group of French Algerians and we see them as agressors. But later, on the beach, their status as human beings is again diminished in a description that evokes a nearly reptilian quality. Meursault approaches the rock where the group of Arabs are lying in the shade. "Mais brusquement les Arabes, à reculons, se sont coulés derrière le rocher" (ETR 91). Treated then as part of the decor, the Arab who is murdered is anonymous. 
And although some critics contend that because the murder of the Arab is not the issue during the trial of Meursault, the Arabs are somehow diminished as a race, I would argue that Camus' focus here is on the absurdity of the trial and development of the character of his protagonist rather than oblique racism. In a colonized Algeria, the Arabs remain in the background without much power or distinction and consequently the novel reflects this historical reality.

In La Peste, the Arabs are virtually absent but we do have some clues in reference to them. Rambert, the journalist, comes to Oran to report on the Arabs' living conditions but he does not pursue the story because he becomes obsessed with his own destiny. In this situation, they are abandoned by one who might speak for them; even the affect of the plague on the poor Arab neighborhoods Rambert was to investigate is omitted. This omission hints that in this once Arab land, the Arabs are no longer central.

The Arabs' circumstances are better represented in "L'Hôte" where the Arabs are at the mercy of the French Algerians. The Arab prisoner is not a stranger in the desert and again through him we see the Arabs inextricably tied to the land. His own skin resembles the desert; it is "...recuite mais un peu décoloré par le froid...." (ER 85). It is not the desert that the prisoner fears so much as he does the French administration, the system that imprisons him and whose justice he does not understand. The Arab children, seduced by the donations, come to school to learn French civilisation: the language, 
geography, and culture. At school the alienation from their roots is exacerbated.

In this story, the Arab is simultaneously "stranger/outsider", victim and enemy with a short respite when he is only a man. When welcomed and accepted by Daru, the Arab prisoner can escape from his role. By sharing a meal, "breaking bread" (a highly symbolic fraternal gesture), as well as by sleeping in the same room with the unshackled prisoner, Daru shows good will that allows the prisoner a kind of equality. However, when Daru refuses to turn over the prisoner in Tinguit, the circumstances change and are misinterpreted; the Arab's comrades threaten revenge. Ironically then, tables turn and Daru becomes the outsider, victim and enemy. Each man's situation reflects the other's.

Arabs depicted in Le Premier Homme like the Arabs in previous works generally remain on the periphery; they are part of the "set", often blending into the background. We know them as outsiders to the colonial society, they stand apart, silent and staring. The "regard hostile" of the Arabs towards the new European settlers accompanies the diminution of their status to "strangers/outsiders" in their own land.

When Veillard's father, the "pied-noir" farmer tears up his vineyard (a kind of retribution for having to adapt to new practices in dealing with the indigenous laborers), the Arabs, like those on the beach in L'Etranger, are immobile, merged with the landscape in the form of stone, a metaphor for their silence and passive presence (LPH 168, 178). Camus repeatedly uses the adjective "immobile" to 
describe them (LPH 177-78) and evokes their impassivity and rigidity in the description of their faces: "visages durs et impénétrables" (LPH 180). These are the same Arabs encountered in "L'Hôte" (the prisoner) and in "La Femme adultère" (the Arabs on the bus and in the streets and the nomads engraved in the landscape).

They are at once attractive and vaguely menacing.

Jacques recalls the uneasiness he felt as a child when he witnessed a fight between a French Algerian and an Arab. When the fight broke out, the Arabs emerged into the street from all directions in a continous movement engulfing the solitary "pied noir" in a sea of dark expressionless faces. The fight and the Arabs' silent reaction leave an impression on the child: "...après leur départ, la menace, la violence, la peur rôdaient pour l'enfant dans la rue, lui séchant la gorge d'une angoisse inconnue" (LPH 258).

Of all Camus' fictional works, Le Premier Homme, contains some of the most distinct Arab characters. And although they have minor roles, there are few that are life-like and somewhat distinct. These individuals are not really "strangers/ outsiders", but rather they enter and integrate into Jacques' universe.

An exception to the stone-faced, formless Arab is found in the opening chapter of Le Premier Homme. "L'Arabe", though nameless, has a face as he is described in greater detail; his physical appearance and a hint of his personality are provided by the narrator. $\mathrm{He}$ talks, smiles, and is generally solicitous. Instead of the distant, statue-like Arabs presented in much of Camus' work, this character is more human like the Arab portrayed in "L'Hôte" (LPH 13-23). 
There are two other noteworthy Arabs. Abder, who works in the barrel factory with Jacques' uncle, connects with the boy when he visits the workshop. (The workshop and Abder's character are intertextual references to "Les Muets" where Yvars works with the Arab, Saïd.) He calls Jacques "mon collègue" which suggests familarity and equality. Later we encounter another "cameo" character in the Arab Tahar, the family's neighbor, who is also cast in a favorable light. $\mathrm{He}$ is not a "stranger" as he lives among the poor "pied-noirs". Considering himself part of the community of the building, he ventures out into the dark courtyard when he suspects thieves are stealing Jacques' grandmothers' chickens. Such a character displaying vigilance and concern subtley points to his fraternal attitude. 
The Mother/Son Relationship

The mother/son relationship surfaces throughout Camus' work; its importance is foreshadowed in a 1935 entry in his Carnets I:

...le sentiment qu'un fils porte à sa mère constitue toute sa sensibilité. Les manifestations de cette sensibilité dans les domaines les plus divers s'expliquent suffisamment par le souvenir, latent matériel de son enfance (une glu qui accroche à l'âme)" (Viallaneix 3).

This "strange feeling" is an element of the story in "Entre oui et non", L"Etranger, and Le Premier Homme. All three works lend themselves to psychoanalytic interpretation of the mother/son relationship. Lazere's treatment of this topic regarding the two earlier texts is interesting as it sheds light on the workings of Le Premier Homme.

The absence of the father (which is the case in the three forenamed texts) intensifies and prolongs the normal stage of pregenital infantile narcissism, Lacan's 'imaginary'. This is a time when the child's identity is not fixed and he/she is like the enfant at the breast still remembering the mother's womb; the child has no fixed center of self. His/Her entire universe is composed of him/her self and the mother, accompanied by feelings of satiety, freedom, wholeness and timelessness. In short, the child inhabits a sort of Eden. Jacques remembers the physical contact with his mother in this stage in "la douce odeur de sa peau" and "l'odeur de la tendresse" (LPH 58). 
The fall from this Eden is marked by weaning and then teething when the child is faced with unaccomodating external forces of time, physical limitations and other people (primarily the father and other siblings) as rivals for the mother's love. This reprieve before maturity results in a sense of suspended time. The protagonist in "Entre oui et non" remembers a moment that approaches this suspended state suggesting that he has not "matured" in a sense. He spends a night in the same bed with his mother who had been attacked. The closeness, the smell of perspiration and the vinegar used to refresh his mother, combined with the stillness of the night ---all seem to dissolve the world and attach him to his mother in a "solitude à deux" (EE 64-5).

During the genital or oedipal stage of development, the child is divided from the mother by the father who symbolizes the prohibition of the child's attachment. Then the child represses the desire to remain in the "imaginary" state and he/she becomes vaguely aware of sexual difference. The absence of a male rival, as is the case for both sons in "Entre oui et non" and Le Premier Homme and Meursault in L'Etranger, creates a huge existential burden on the child who must forge his own identity without a sign of difference and a model to emulate. According to Lacan, the child must perceive relations of similarity and difference for him/her to successfully move into what he calls the 'symbolic order', " the pre-given structure of social and sexual roles and relations which make up the family and society" (Eagleton 167). This is, of course, one of the 
problems for Jacques Cormery who attempts to re-imagine his father after the fact.

The fatherless male child resents the mother for forcing him to grow up but also fears being devoured or castrated by her as she assumes the Super-ego role. This can be very threatening as she is the only other oedipal figure. In Jacques' case, the Lacanian differentiation appears to be incomplete; this may be due to the blurring of roles in the family where his grandmother (embodying more Animus) becomes the parent (mother and father) for both the children and the adults. Jacques is distanced from his mother in two ways: 1) her seeming indifference (which he later understands) and 2) the grandmother's presence as 'the Law' (in Lacanian terms). Hence, the mother and grandmother force him to grow up and be a "man".

Pre-oedipal narcissism cannot be heathily prolonged even in a fatherless son because inevitably other oedipal threats surface. In Jacques' case the grandmother represents to a limited extent, 'the Law', although there is no actual sexual difference. The child's harmonious attachment to the mother is interrupted by the maternal grandmother who assumes a position of authority in the family. She organizes and directs the household, establishing rules and punishing the children. To some degree, Jacques' desire for his mother is repressed as a natural reaction to 'the Law', however, this unfulfilled longing surfaces regularly.

In surrogate fashion, the grandmother helps establish this critical acceptance of sexual difference and distinct gender roles. 
One example of her endeavor to socialize Jacques to be a "man" (according to the norms of that particular society and time) is embodied in the incident of the killing of the chicken. Appealing to his courage (as a "man"), she challenges him to descend into the dark courtyard to fetch a chicken to be slaughtered. Jacques must conquer his fear and disgust. The incident might be considered as a sort of initiation into his role as a man in the family.

At this point, the child longs for a father not only as a masculine model but as an ally. The anecdote in which the child Jacques is told of his father's reaction after attending a public execution points out the child's unconscious identification with the father. No details are spared in the retelling of the story by his grandmother (she and a few male characters provide Jacques with information about his father) and Jacques ends up dreaming of his own execution by guillotine (Lazere points out that decapitation is a classic symbol for castration) which can be easily linked to the father who had suffered a similar death (his head was blown open) in battle. (Identification with his father may be fueled by the boy being told that he is the "spitting image" of his father.) Such images continue to haunt him throughout his life which points to an unresolved oedipal stage which eventually is a catalyst for the quest for his father (LPH 80-1). (A version of this story of a father seeing an execution found in L'Etranger, La Peste, and "Réflexions sur la guillotine" seems to be a preoccupation that suggests unconscious fears on the part of the author.) 
Jacques acknowledges an unexplained connection with his father's death and the story of his witnessing of an execution, however, his mother's reaction of acceptance of the violent death of her husband as just another of her life's misfortunes is anxietyproducing for Jacques.

Mais c'était un lien mystérieux qui le reliait au mort inconnu de Saint-Brieuc (qui lui non plus n'avait pas pensé, après tout, qu'il pût mourir de mort violente) par-dessus sa mère qui avait su cette histoire, vu le vomissement et oublié ce matin-là comme elle avait ignoré que le temps avait changé. Pour elle, c'était toujours le même temps d'où le malheur à tout moment pouvait sortir sans crier gare (LPH 81).

These feelings of identification with his father surface at the grave site when Jacques can empathize with his father as "l'enfant injustement assassiné" (LPH 30).

The image of decapitation (as a symbol for castrastion) can be associated with the mother's lack of intellect. In the intertextual scene from "Entre oui et non" repeated in Le Premier Homme, the boys are both caught staring at their mothers (trying to stay fixed in the past) and are told to "faire les devoirs". Both do, and consequently this turning away and doing what "must be done" represents a certain rejection of the identity of the mother. When the adult Jacques Comery goes to the cemetary, he sees a boy doing his homework. This represents the path Jacques took and is a "mise en abymen of his eventual separation from his mother and his home That road has brought him to seek his father. Certainly for Camus, his strivings for intellectual development and his valuing of clarity 
may be construed as an attempt to be a man, that is, to have in a sense a male identity distinct from his mother's.

As for a case of sibling rivalry in the three texts, none is developed. Henri/Lucien in Le Premier Homme is the only brother mentioned. As an older brother, he is well-placed to be a substitute oedipal rival yet his role is so minimal that he finally disappears from the text. Is this elimination a kind of fratricide? None of his appearances in the text gives an impression of hostility and there is definitely not any preoccupation with his character. There is, however, a curious hesitation at the beginning of the text about the presence of a brother; first he is in the cart accompanying the family (LPH 12) and then he has been left behind and is not present at Jacques' birth (LPH 20). The sub-text suggests two possibilities: that Camus is either denying any competition and the brother is in fact a threat, or in fact, the rivalry is nonexistent.

Fraternity is, ironically, a favorite theme of Camus. Nonetheless, biological brothers are conspicuously absent from his work. An exception occurs in L'Etranger where the brother of Raymond's Arab mistress takes on the paternal role by avenging his sister's beating and becomes Meursault's victim. The humanitarian solidarity depicted in the body of Camus' work appears to have become a preferable and perhaps non-threaten ing version of his love for others.

A feminist reading of Camus considers the maternal in a positive light (Mostaccio in King 155) rather than focusing on "lack" suggested in a pure Freudian interpretation. Camus' is an 
archetypal universe where the Algerian people are "a whole race born of the sun and sea" ( $N$ 26). Here the feminine principal is frequently represented by the sea while the sun is dominant and masculine. Logically, he links "la mer" to "la mère". In his world, both have extraordinary value.

For example, in L'Etranger, Meursault goes immediately to the beach the day after his mother's funeral, and makes his first contact with a woman, Marie, while swimming in the sea. The celebrated swim in La Peste where Rieux and Tarrou find a fraternal bond and a sense of suspensed time in the water also suggests the "mer/mere" connection.

Jacques and his friends swim naked in a sea that is "douce, tiède" (an amiotic fluid) which suggests a return to the womb. Their euphoria and sense of timelessness is painted in the after-school beach scene where they are so delighted that they forget the time and must race home before dark (LPH 54-5).

The sea, like most elements in the Camusian universe, has its "l'envers et l'endroit". Crochet's discussion of symbols in the JudeoChristian tradition gives insight into "l'envers" of the sea (water). The sea framed the world; it was the edge of the earth, the abyss where one would be swallowed up. Therefore, it was feared and was at certain points something to be overcome. In the parting of the Red Sea, the terrified exiled Jews had to have enormous faith to be able to walk between the walls of water. God (the Father) allows them to pass through safely. (Crochet 200-1) 
Uncle Etienne/Ernest as surrogate father becomes an "ally" helping Jacques overcome his fear of the sea. Jacques perches on his back ; the uncle, as intermediary, keeps him from being swallowed up by the sea. Similarly, the uncle's presence in the home (even given his limited ability to communicate) provides a balance to the child's unconscious fear of being overcome by the "feminine" in his life.

Jacques grows up loving to swim in the sea because his uncle shows him how to master it. Quilliot states: "Nager, c'est communier physiquement avec la mer mais aussi puisque la nage ne nous est pas naturelle---la maitriser" (38).

\section{Nature}

Anna Balakian notes that Camus' writings go beyond the "naturalist" movement of the 19th century because his characters are raised above the socio-ethnic context and are related to the more universal facets of the human condition. His ontological meditations stretch outside man-made interiors and are cast against the background of natural phenomena.

Natural elements are not allegorical constants, but rather varying symbols which cipher man's troubled being and gauge the vulnerablility of his existence on the basis of the alienations and communions which he experiences. These considerations superpose on the geographical vision a metaphysical one... Climate and landscape invade temperament and inscape on several levels. They create correspondences with body signs; they are significant in the premonition of 
catastrophe, in the recognition of cosmic truth, and the process of self-illumination (Balakian in Zyla and Adcock 38). Further, climate in a number of Camus' works, forecasts change; there is a movement from static to dynamic resulting in tremor, eruption, restlessness, crisis, or self-revelation.

In Le Premier Homme, descriptions of the natural world correspond with psychological and historical as well as the metaphysical movements of the characters. The initial scene as the narrative opens contains as a backdrop the description of the approaching storm that has made its way from the Atlantic across the Moroccan mountains to the Algerian plateaux only to be lost in Tunisia. Camus links the clouds' "course de milliers de kilomètres au-dessus de cette sorte d'île immense défendue par la mer mouvante au nord et au sud par les flots figés des sables passant sur ce pays sans nom..." to the people and empires who for centuries had come and gone (LPH 11). Like the storm, the settlers would have a brief impact and be forgotten; the eternal forces of the sun and wind triumph. The only evidence of the clouds passing is the light rain falling on the travellers. Correspondences between the passing storm that had come from afar and the Cormery family's long journey (and subsequent premature departure from their new home) function as a foreshadowing. Similarly, as the rain cleanses and replenishes the earth, the child born that rainy night is symbolically "baptised" for a future communion with the natural world. 
I examine the cemetery scene in the following chapter to demonstrate the interplay between "inscape" and climate and landscape. Here, Camus works with the antithetical imagery of life and death in the exterior world as Jacques enters a journey of selfdiscovery (not unlike the heroic journey in mythology). These images are perfectly balanced; they are juxtaposed alternatively. First, the caretaker/ guard (a character crucial in the heroic journey) guides him and informs him as he passes into a new realm of experience. The caretaker gives Jacques an opening to express his grief to which he responds honestly as did Meursault in L'Etranger. (This is the first striking parallel between Meursault and Jacques Cormery. In this scene, the reader soon detects that Jacques is tuned in to his physical surroundings as was Meursault.)

When Jacques approaches the section where his father is buried, he notices that the stones are identical and arranged in even rows suggesting the universality and regularity of death. The presence of fresh flowers (symbol of beauty and life) contrast with the tombstones and correspond to Jacques' vitality. Like Meursault at his mother's burial, Jacques is distracted and looks up at the sky. At first, he is drawn by nature more than to his father's resting place. "Le ciel plus pâle, des petits nuages blancs et gris passaient lentement, et du ciel tombait de tour à tour une lumière légère puis obscurcie " (LPH 29).

The sky's paleness reminds one of the palor of death. It is obscured here by the slowly passing clouds both gray and white which can be given a symbolic value of confusion and innocence respectively but 
they more likely forecast Jacques' transformation, his awakening to his connection to his father. The faint light tries to penetrate the clouds as Jacques himself becomes "enlightened" in a new awareness. At this juncture, Jacques realizes the irony of his "perre cadet", the futility of his desire to know the world, and the possibility of self-awareness in the acknowledgement of his father as an actual man who had had a past and a future. Thus, we are able to trace his epiphany in the cemetery and new desire to rediscover his father in the movement of the horizon.

In this scene silence reigns, evoking the dead who cannot speak, while in contrast, the faint murmuring from the town reminds us of life beyond the high walls surrounding death, and ultimately, the life that the father had had. Juxtaposed with the din of life in the town, another image of death, the black silhouette moving among the tombstones, evokes the work of mourning. Next is a subtle correspondence with Jacques' inner landscape; he gazes at "la lente navigation des nuages dans le ciel" and tries to move beyond the confines of cemetery (suggested by the smell of wet flowers), the place where he must confront his father's death, through the salty air coming from the sea (the sea representing the maternal and in this case, his living mother). What awakens Jacques is the sound of a bucket against the marble surface of a tombstone. The man-made metal chinking against the stone represents the human presence knocking up against the permanence and indifference of nature. The sound redirects his attention and prompts Jacques to read the dates on his father's headstone. Realizing his father had been much 
younger when he died than he himself is, Jacques feels for the first time compassion for this absent father and can begin to relate emotionally to his father's being and death. In acknowledging both, Jacques takes another step in his " journey"; he has the possiblity of gaining a greater awareness of life (in the existential sense) and a greater self-awareness.

The text then moves from the "inscape" where life has a new focus back again to the exterior world, the declining afternoon. Simultaneously, the sound of a skirt and a black shadow, interject correspondences with the maternal and death. He has acheived the first phase if his "journey"and knows it is time to move on. The silence is again broken but this time by the detonation of a plane breaking the sound barrier. It is at this moment that Jacques turns his back on his father's tomb. The image has a dual value. First, the modern aircraft hurling across the world at incredible speed giving the impression of transcendence contrasts with the silence of death, our human fate. Secondly, the loud booming is reminiscent of the sounds of the battlefield and the wounding of the father.

The sun, a constant in Camus' imagery, is anthropomorphized into a powerful divinity. L'Etranger, Noces, L'Eté, and La Peste all contain examples of this. In the essays, the sun is the object of physical worship and contributes to the author's love of life in the natural world. For example in "Retour à Tipasa", the sun is the insatiable sky that devours its victims who lie on the beach in crucifix fashion (L'Eté 166). King sees the sun's presence in L'Etranger as a representation of the external world with which man 
struggles. As Meursault encounters the limitations that the universe places upon his desires, Camus is creating a concrete image of what he terms the absurd confrontation between man's desires and the universe's indifference. Meursault is especially aware of the sun's heat which frequently saps his energy. Subsequently, the opposition between Meursault and the sun culminates in the murder scene. The sun's astounding god-like power is blinding and unbearable as it reaches its full intensity causing Meursault's senses to be confused. He knows that it is senseless to walk towards the Arab but he is unable to resist. Thus his actions can be interpreted as a defense against the overwhelming sun, his oppressor (King 54). What compels Meursault are two drives: simultaneously to extinguish and to imitate the power of the sun. These are not unlike the dual Oedipal drives to seek out the father and then to kill him (Mailhot 264). This "revolt" against the sun as universal father is evoked during the trial when the prosecutor compares Meursault's case with a subsequent case on the court's agenda, a parricide (ETR 156).

In Le Premier Homme, the sun has positive and negative attributes comparable to those treated in these other works. Strong imagery reinforces the power of the sun's divinity as both awesome and fearsome. For Jacques the sun is "son seigneur" endowing him with a sense of himself as "le plus riche des enfants" (LPH 106).

At the same time, the sun at its peak in summer had "ses sujets" as well as "ses prisonniers" (LPH 106). "Le soleil règnait 
férocement... abattant les chiens et les chats, obligeant les êtres humains de raser les murs pour demeurer dehors de sa portée" (LPH 237-8). This is the same summer sun depicted in La Peste: " Le soleil poursuivait nos concitoyens dans tous les coins de rue et s'ils s'arrêtaient, il les frappait " ( $P$ 106). Nothing is safe from the sun's omnipresence.

The absolute power of the sun to crush, penetrate, and compel occurs throughout the text. On the hunting expedition with his uncle Etienne/Ernest, Jacques feels himself bending under the beating sun that simultaneously pounds the earth like a hammer beating an anvil. The effect is hallucinatory; the plateau seems to vibrate. Likewise, when Jacques and his friends are running to the beach, they are assaulted by the "dur soleil" (LPH 56). Another image of the Algerian sun igniting the sea, "la mer en flammes" reinforces its power (LPH 137). Jacques recalls how at school the lessons engaged the students while outside the sun seemed to be demanding attention and though invisible it penetrated the walls and shuttered windows. Camus' synesthetic description accentuates the sun's assault on the senses: "...le soleil pouvait hurler sur les murs fauves pendant que la chaleur crépitait dans la salle elle-même" (LPH 136).

The sun's transformational power affects both the earth and human beings. First, under its influence the landscape is altered.

Le soleil de plus en plus fixe, de plus en plus chaud, avait séché, puis désséché, puis torréfié les murs, broyé les enduits, les pierres et les tuiles en une fine poussière qui au hasard des vents, avait recouvert les rues, les devantures des magasins et les feuilles de tous les arbres (LPH 237). 
We find that simple men like Meursault are rendered insane by a ferocious sun; that is, the sun has the power to draw out the dark side, the innate, violent side of the psyche that is explained in Le Premier Homme as being related to the "first family" in Cain's killing of his brother. The old doctor from Solferino explains the brutality of the Arabs and the pied-noirs towards each other: "les hommes sont affreux, surtout sous le soleil féroce" (LPH 177). But Jacques already understands the sun's force because as a child he had witnessed the power of the sun's oppressive heat. $\mathrm{He}$ remembers how an Arab barber while shaving a customer had slit the man's throat without any provocation.

Ah oui, la chaleur était terrible, et souvent elle rendait fou presque tout le monde, plus énervé de jour en jour et sans la force ni l'énergie de réagir, crier, insulter ou frapper, et l'énervement s'accumulait comme la chaleur elle-même, jusqu'à ce que, dans le quartier fauve et triste, de-ci de-là, il éclatât ... (LPH 239)

"Quartier fauve" is significant because it emphasizes the animalistic quality of the inhabitants who like Meursault are creatures sensitive to their surroundings especially vulnerable to the sun. The city Oran and its inhabitants in La Peste showed a similar vulnerability; as the heat rises, the plague is exacerbated and violence breaks out of the city gates as citizens clash with the gendarmes ( $P$ 107).

Returning to Algiers as an adult, Cormery recognizes "le même soleil" from his childhood. While the human landscape had visibly changed with time, the sun remained immutable (LPH 45). 
In opposition of this splendid sun is darkness. Our protagonist's dread of nightfall is more than a residual childhood phobia of the dark originating in the dark hallway and courtyard of his apartment building, and the streets of Belcourt. As a child, he instinctively reacts to the approach of evening; he rushes home to the safety of his humble family for he has seen his own Belcourt transform. In fact, one evening his family must walk by a murder scene. When the boy spends the night at his aunt's farmhouse, the house is secured from the unspoken menace of the Arabs. Therefore, the boy cannot help but associate nightfall with threat and fear.

The anxiety produced by the absence of light (when unconscious fears surface and men and women join their own solitude) is mentioned several times in Le Premier Homme. At dusk, the "angoisse" experienced by Jacques and Veillard, we are told is universal in Africa where the people are connected to the natural world. (LPH 179) The end of the day stirs the awareness of mortality and of one's own "dark side". Certainly, they had begun to see the face of inhumanity in their own country.

Camus extends the image of the anxiety produced by the absence of light from a primal fear and transforms it into a metaphor for the trepidation of confronting the worst of human nature. Whereas the image of light equated with Algeria's sunshine, the greenish Mediterranean light, is often a symbol of strength and truth, darkness symbolizes the horrors of Camus' time. Having grown up between the wars, the writer had witnessed some of humanity's darkest hours. Thus, nightfall evokes the "darkness" of the death and 
torture suffered under Facism, Nazism, Stalinism, and during the Algerian conflict.

Jacques' memory of the wind has a binary value like the wind in Djemila in the essay in Neces. Its force is at once exhilerating and overwhelming; in their invented game with the palms, Jacques and Pierre fight against "la force enragée du vent" (LPH 224). So intense is his experience that Jacques still hears the tumultuous fury of the wind when he goes to sleep at night (after playing that day with Pierre at Kouba). He would continue to love its power and energy throughout life (LPH 224).

The continued role of the natural world throughout Camus' work and its significance in Le Premier Homme reveal his neo-pagan tendencies influenced by the ancient Greek world view where the sun, sea, and body are all celebrated. His brand of veneration of nature implies reverence and fear, as well as desire for communion in spite of the inevitable result of alienation. 
CHAPTER ॥

PRIMARY INFLUENCES ON THE FORMATION

OF CAMUS' "PREMIER HOMME"

Influences

Obviously, as an unfinished text, Le Premier Homme, presents to the contemporary reader only a portion of the portrait of Camus' "first man". Most of this portrait hinges on the early formation of Jacques Cormery and the primary influences of his youth. These include his forgotten and enigmatic father, surrogate fathers, his grandmother, and several close friends. Each is remembered in detailed anecdotes which help the subject understand his identity. (His crucial relationship with his mother has already been discussed in the chapter on themes.)

The Father

The absent father is not new in Camus' work. Neither the subject in L'Envers et l'endroit nor Meursault, nor Rieux has a father. These characters tend toward the maternal while rejecting or rebelling against the paternal. In Le Premier Homme, a transition has been made; the subject is certainly caught up in his maternal connection, however, he is consciously, although at first unconsciously, seeking the paternal, the missing father, which will eventually create a balance. The equilibrium, symbolically 
shattered by Meursault in L'Etranger, is being re-established in Le Premier Hemme.

Not only did Henri Cormery die when Jacques was an infant, he did not live on in the family's memory. Indeed, he was a stranger primarily because there was little tradition or knowledge transmitted orally due to the mother's enduring silence and to the fact that the adults in the household were illiterate. And yet despite the limited connections to this forgotten father, his influence is precisely found in his absence. The boy is left, the narrator tells us, to raise himself; he is left to think independently as he was not given a set of beliefs or absolutes.

The mother who possessed a few postcards sent by the father from the front in France and a piece of the shrapnel that killed her husband had forgotten him. Immobilized in her own pain and hardship, she could not sustain his memory. Nontheless, there is a faint identification with the father when Jacques learns that he physically resembles his father. He hears one anecdote (from his grandmother) and because it was so isolated and its content so revealing, it haunted Jacques throughout his childhood. This was the story of the father attending an execution and then returning home to become violently ill and unable (or unwilling) to speak about the incident. In this solitary image of his father, "the "seul héritage" bequeathed to him, the boy can identify with his father's sensibilities which readily enter his psyche. The impact of this account can be interpreted in a number of ways including the 
philosophical as well as the psychological implications (as presented in my discussion of the mother/son relationship).

One way the father is present is in the family name, Cormery, which curiously contains the phonemes for "corps" and "mer/mère", all of which are critical Camusian themes and underline components of Camus' Algerian man's value system (L'Eté 87). Ironically, the name is not fictional. It is, in fact, Camus' own paternal grandmother's maiden name which on another level aligns the protagonist with the father but via the maternal. His first name is "Henri" which means "ruler of the home". Indeed, Jacques belatedly realizes that this is exactly what he had been lacking---he needed his father to be an authority, a guide for him as a man. A revelatory note in the text written in the first person indicates the impetus behind Jacques'/Camus' search:

J'ai essayé de trouver moi-même, dès le début, tout enfant, ce qui était bien et ce qui était mal---puisque personne autour de moi ne pouvait me le dire. Et puis je reconnais maintenant que tout m'abandonne, que j'ai besoin que quelqu'un me montre la voie et me donne blâme et louange, non selon le pouvoir mais selon l'autorité, j'ai besoin de mon père (LPH 40).

And, although a number of surrogates had filled the fathers' role to varying degrees, the mature Jacques Cormery still needs his father.

When the 40-year-old Jacques sets out to "know" his father, he learns that his father, like his mother, spoke little therefore, he can expect to encounter another silence surrounding the father even outside of the family among the father's peers (those who had not perished in the war). However, a second significant anecdote does 
emerge, allowing Jacques to come closer to an understanding of his unknown father, when Jacques speaks with the former director of his primary school, Monsieur Levesque, who had served in the same unit as the father during the Moroccan war. His impressions of the man include qualities reflected in the son: "Dur à la fatigue, taciturne, mais facile à vivre et équitable" (LPH 65).

A more solid portrait of the enigmatic father begins to form. Jacques finds Henri Comery, a poor laborer who accepts his destiny and refuses to be beaten down. Monsieur Levesque tells of one instance when Henri is confronted with the barbarity of war (he sees men who have been multilated by enemy soldiers). Visibly shaken, he denounces such acts and categorically refuses any rationalization about the nature of men during times of war.

Surrogate Fathers:

Uncle Etienne/Ernest and Monsieur Bernard

\section{Uncle Etienne/Ernest}

Inevitably, an orphaned boy will seek out substitute fathers and this is precisely what young Jacques did. The two men who took up those roles contributed enormously to the extraordinary evolution of the young "pied-noir" born into a poor, illiterate family. Each, according to his gifts, overlooked an aspect of the boy's formation: one influences his physical development, another sets the stage for his intellectual development. As Jacques looks back on his 
childhood, he fondly remembers his first father figure, Uncle Etienne/Ernest. This most prominent early father substitute lives with Jacques, his mother, brother, and grandmother, and works as a barrelmaker (like Yvars in "Les Muets"). Etienne/Ernest initiates Jacques into the physical world of the Mediterranean man. Jacques is able to see his uncle at play and at work. In his leisure, Etienne/Ernest gives him his taste for swimming and a love of the sea as well as exposing him to the joys of hunting and the company of other men. As a guide, he is gentle and loving. Etienne/Ernest's quasi-animal presence makes an impression on the child. A speech impediment causes him to communicate in phrases punctuated by grunts and gestures (almost mime). His strange articulation, joined with his simplicity and illiteracy, reinforces the obstacle of communication and the lack of verbal reinforcement in Jacques' home environment.

The uncle communicates best with his dog, Brillant. This peculiar "couple" is an intertextual reference to Salamano and his dog in L'Etranger who in return reflects the mother/son couple (Maman/Meursault). In the nursing home, Meursault's mother pairs off (with Thomas Pérez). Similarly, in Le Premier Homme, the uncle/Brillant symbiotic rapport contrasts with Jacques' relationship with his mother, especially in the realm of affection. In old age Etienne/Ernest is by circumstances paired off with Jacques' mother; they live, by force of habit, as a couple. These "couples" seek to escape their respective solitudes. 
Etienne/Ernest's "innocence adamique" renders him an endearing man-child inspite of his impetuous nature. Camus' portrait is that of a man whose strength and vitality explode in both his physical life and the expression of his feeling. The depiction of the uncle provides some comic relief especially in the anecdotes of his highly developed sense of smell, his scatological illusions, and his hilarious miming.

The uncle instills in Jacques a love for the simple" pied-noir" working class in addition to providing Jacques with a sense of security (for the boy had proof that Etienne/Ernest loved him). By exposing Jacques to his workplace, Etienne/ Ernest gave him an appreciation for what hard work was. When Jacques is hurt in the workshop, his uncle rushes him to the doctor and then after the incident, smothers him with affection. This overt display contrasts with the mother's seeming indifference. On another occasion after a day spent hunting, Uncle Etienne/ Ernest responds to Jacques' taking his hand by squeezing it tightly.

Finally, Etienne/Ernest is really Jacques' model of virility. He provides a crucial balance to the feminine energy that surrounded the child daily. While exposing Jacques to a "man's world", he is also a vehicule in reinforcing Jacques' connections to the natural world whether it be swimming in the sea or trekking across an arid plateau in the burning sun. 
Monsieur Bernard

While Jacques' uncle encourages the boy to take pleasure in the physical, another man impacts Jacques' early intellectual development and eventually his destiny. Monsieur Bernard, Jacques' perceptive and dedicated primary school teacher engaged all his students by giving them the opportunity to think and make their own discoveries. The narrator tells us that instead of dulling their natural curiosity, he understands how to nourish it (LPH 138). He is both loved and feared.

It is significant to note that in the chapter entitled "L'Ecole", Camus introduces the teacher as Monsieur Bernard, but ten pages later, in the same chapter, the writer slips and calls him Monsieur Germain, a reference to Camus' real teacher who is the obvious model for this character. This lapse occurs when he describes the teacher's unique attitude towards the boys in his class.

Dans la classe de M. Germain. pour la première fois ils sentaient qu'ils existaient et qu'ils étaient l'objet de la plus haute considération: on les jugeait dignes de découvrir le monde (LPH 138).

Camus applauds the teacher for recognizing the key ingredients for motivating pupils universally: respect, self-esteem, and empowerment. Bernard's/Germain's effectiveness is due to other factors which include his passion for teaching,and his ability to reveal personal experiences and present different points of view, not only his ideas and opinions. At a young age, Jacques learns from 
the teacher to respect those whose ideas and convictions differ from his, a first step towards fraternity.

As a second authority figure (the grandmother being in the first position), Monsieur Bernard is quite strict but has a sense of justice. Like the grandmother, he does not hesitate to use corporal punishment (in the form of his notorious "sucre d'orge", a well-worn ruler). His severity, however, is balanced with great affection and dedication. Later when Jacques moves on to the "lycée", he reflects on the unique role of an "instituteur" as opposed to the "lycée" level teachers; the former are esteemed and feared like fathers out of necessity, not by choice. He recognizes the fact that he and the other boys completely depended on this man (LPH 203).

Jacques becomes the "chou-chou", Bernard's pet, a fact that the teacher is ready to defend; he tells the class that he feels a responsibility for all boys in his class who have lost their fathers in the war, the war in which he served for four years. He tries to serve as a surrogate and a model in place of these deceased fathers. In one anecdote, Monsieur Bernard outwardly shows his affection for Jacques which leads to a remark by one of the class members but the teacher is ready to defend his actions as part of his mission. Nevertheless, in spite of his preference for Jacques, the boy is treated with impartiality when it comes to discipline. He, too, must submit to the "sucre d'orge".

Monsieur Bernard, as the boy's first teacher, is credited for opening up his world through reading. Jacques' love of books is inspired by stories read by this teacher. Initially, Monsieur Bernard 
brings the recent war (WWI) to life by recount- ing his own experiences and then, subsequently, his choice of literature dwells on heroic tales of this same war. His students are quite engaged as they much prefer these to the fairy tales read by other classes. One book in particular, Les Croix de bois, offers a glimpse of the exotic in addition to the excitement of battle, and captures the boys' imagination. They discuss the characters as if they were old friends, and although the subject of the story is war (and takes place on the same battlefield where Jacques' father is killed), it never occurs to them that these heros could become victims (LPH 140).

At the end of the book and the demise of the hero, Jacques bursts into tears. His vivid imagination allows him to completely identitfy with the characters and action of the story but Camus also suggests that the boy's unconscious is tapped; he has never grieved the loss of his unknown father nor had occasion to do the work of mourning this loss. Subsequently, many years later, Monsieur Bernard gives the book to Jacques as a gesture of his enduring affection. The implication is that this first mentor is offering both a souvenir of Jacques' youth and way to envision his father's experience.

Thanks to the perceptive Monsieur Bernard who recognizes his gifts and his potential, Jacques is given the opportunity to win a scholarship and continue his education in spite of his family's circumstances. The teacher's critical intervention and appeal to Jacques' mother and grandmother, his time in preparing Jacques for 
the exam at no expense, and his confidence in his student all witness to his love and commitment which change Jacques forever. Camus' effusive description of the teacher betrays his own great affection for the man who profoundly altered his life: "...c'était lui qui avait jeté Jacques dans le monde, prenant tout seul la responsibilité de le raciner pour qu'il aille vers de plus grandes découvertes encore" (LPH 149).

The Grandmother

Jacques' maternal grandmother's influence cannot be underestimated; she was in many respects both parents. While he idealizes his mother, the older woman is presented in a more negative light. Throughout the text an ambivalent portrayal permits the reader to draw his/her own conclusions.

Bitterness clouds the adult Jacques' memory of his grandmother, the family matriarch who forced him to take naps with her during the torrid summer afternoons. Our initial picture of her is that of a heavy-handed autocrat. Jacques remembers her trying to squelch his unbounded energy by requiring him to rest when he was aching to rejoin his friends to run and play. As a result, this mature man still resists the habit of a nap, a practice that makes him feel nauseated if he attempts it after lunch. While he continues to admire his mother's beauty as she ages, his memory of the aging grandmother focuses on the unattractive image of her veiny feet covered with age spots. 
Indeed, this woman had endured hardships in the past and then was saddled with the burden of running the household. She had married young and lost her husband after bearing nine children. Of the seven surviving children two (Catherine, Jacques' mother, and her brother), both handicapped came to live with her. Neither adversity nor poverty had crushed her; her lack of resignation in the face of the unfortunate circumstances of her life left an impression on Jacques.

With a fierce vitality, she dominated both her children and her grandchildren who lived in fear of her. Her definite ideas about child-rearing included submission to authority with the threat of physical punishment. The boys' indisgressions are met with lashes of a bull whip.

Like the grandmother in "L'Ironie" from L'Envers et l'endroit, Jacques' grandmother dominates her daughter. In the face of conflict, she becomes passive-agressive and resorts to a chilling silence. When Catherine cuts her hair (shortly after receiving the visits of her brother's friend, Antoine), her mother blurts out in front of the boy that she looks like a whore, and then refuses to speak to her for several days (LPH 116).

Jacques, with an innate determination to live and love life, clashes with an equally determined grandmother who struggles to help her family survive by controlling the pocketbook. She forbids the boys to play soccer because the soles of their shoes would wear out too quickly and she regularly verifies to see if this interdiction 
has been violated. Beatings are the price her grandson pays for his beloved soccer.

Her stubbornness and determination are best illustrated in two events: her pressuring the priest to allow Jacques to make his first communion by an accelerated course to be done in a month and by forcing Jacques to lie about his age and circumstances in order to obtain a summer job. As a cultural Catholic, she has in her mind an idea that this is something that a child does, a kind of social rite. (There is also the implication that the family might profit from the gifts he would receive.) Jacques must work as every bit of income anyone in the family can earn would help.

Within the family, the grandmother plays the role of judge and jailer. She rules by fear and threats. In her long black dress she makes pronouncements that become for the boy frightening prophesies; Jacques is frequently reminded of his most certain fate for misbehaving-the scaffold. As mentioned previously, the possibility of such an end haunts the boy because he carries the memory of his father attending an execution. A sense of guilt and fear is tied to the memory of the grandmother.

The Cormery brothers are victims of the grandmother's manipulation as well. For example, she appeals to their pride in order to get them to bring in a live chicken from the dark courtyard to be slaughtered. When Jacques the younger brother succumbs to the pressure, she humiliates the older one by pointing out the fact that his little brother isn't afraid (LPH 212). Out of pride and volition, Jacques summons the courage to descend into the darkness. 
This episode points to her insensitivity to the children who found the ritual of trapping the chicken and killing it in the kitchen distasteful.

Jacques suffered tremendous conflict when his grandmother forces him to lie about his age and availability in order to get a job. While he acknowledges that he was capable of lying about petty things to family and friends, he dreaded lying to strangers (LPH 242). Not only did he feel fear and vulnerability when contemplating future results of such a deception of potential employers, he regretted the sacrifice working would entail---he would be giving up a summer of freedom in the sun for a monotonous job. His grandmother's insistence that he work meant sacrifice and dread; with the approach of September 15th, the first day of school, he would have to inform his unsuspecting employer who had believed that the boy was training for a permanent position with the company. Although the grandmother assured Jacques that she would take care of things when the time came, he is left to confront his boss with the deception (243-50).

The narrative, told from Jacques' point of view, does nonetheless allow the reader to empathize with the grandmother. We know that she has suffered, that she has lost her husband, her son-in-law and all of her nephews, that she must take on the traditionally paternal role of the authoritarian, and that she is motivated by her family's survival. We are privy to her looks of sadness and pride that reflect her ambivalence about the gamble the 
family is taking by allowing Jacques to go to school rather than work.

On the positive side, the grandmother is one of the few people who provides the boy with some access to the memory of his father. Also, she does express pride in Jacques' acheivements (which no doubt provide some vicarious pleasure). She is enthusiastic about his awards and shows off both her grandsons when her daughters come to visit. The boys are called on to perform by singing and playing. Ironically, the grandmother's favorite song is the sad song of a young woman who is singing among the crowd at her lover's execution (a "mise en abyme" of the family tale about the Henri Cormery's attending an execution).

Despite her severity, the old woman does show her affection on one occasion. On the day that Monsieur Bernard comes to advocate Jacques' preparing for the "lycée" and continuing his education, he communicates to both women his confidence in Jacques' giftedness. After accepting, the grandmother holds his hand with "une sorte de tendresse désespérée" and calls him "mon petit" (LPH 153). 


\section{Jacques' Childhood Friends: \\ Pierre Marlon and Georges Didier}

Two of Jacques Cormery's peers gave him love, friendship, and insight. These relationships are as important as his relationships with the adults who helped to shape him. Jacques' relationship with Pierre Marlon, his best friend, develops his sense of friendship and fraternity. The boys are "...frères par l'origine et le destin" (LPH 131) as they share similar backgrounds and similiar interests. An only child, he too is a war orphan who lives with his mother. Jacques and Pierre love to read and enjoy hours of vicarious adventure through books. From an early age, the two play together, rejoicing in the sun,wind,and rain, wandering the streets, and frequenting the local library. Both are enthusiastic about the street games that occupy the neighborhood children, however Pierre is less proud, never gloating after beating Jacques.

Their initial bonding occurs in relation to school because Pierre, a year older, took Jacques to school. Pierre was bright and wellbehaved at school, and also a bit more serious than Jacques. Both were at the top of their class and thus singled out with another boy to compete for entrance into the "lycée". Although their temperaments were quite different---Pierre being more reflective and secretive---they got along well. In fact, their physical appearance complimented each other's as much as their 
personalities did. While Pierre is fair and blond, Jacques is dark and brunette. Pierre is shorter and slighter than Jacques, but he is skillful.

The two young "pied-noirs" also share a sensitivity and innocence that point to their humble backgrounds. When the neighborhood gang goes out to hunt "cocoses", a small, sweet, orange fruit, by knocking them out of the palm trees with stones, Pierre and Jacques who are good shots amass a quantity of the savory fruit. Both share their "loot" with the less fortunate, less skilled members of the group. In Kouba at the Maison des invalides, where Pierre's mother works in the laundry, the boys entertain themselves by mixing potions made with herbs and plants. They pretend that their concoctions are poisonous yet they never imagine targeting a victim. Never did they once fantasize about ridding themselves of an undesirable teacher or classmate because there was no one they hated. The text implies that they maintained this innocence beyond the lazy days of a childhood summer: "Mais c'est qu'en vérité ils ne détestaient personne, ce qui devait beaucoup les gêner dans l'âge adulte et la société où il devaient vivre alors" (LPH 223).

Another example of the boys' innocence lies in their acceptance, without sadness, of the disabled war veterans in the Maison des invalides. When Pierre's mother explains that the men had lost arms and legs in the war, they accept the tragedy as a fact of life; after all, the war had influenced so may things around them. War was to 
them just a period in life when one lost an arm or a leg (LPH 220). They had lost their fathers.

From their early days at primary school and on through the "lycée" years, the boys were fast and loyal friends. They continued to share the daily adventure of a commute to school when they cross town by tramway to attend the "lycée". It is in the "lycée" where they meet students from bourgeois families that their commonality is accentuated:

Jacques, et Pierre aussi, quoique à un moindre degré, se sentait d'une espèce, sans passé, ni maison de famille, ni grenier bourré de lettres et de photos, citoyens théoriques d'une nation imprécise où la neige couvrait les toits alors qu'eux-mêmes grandissaient sous un soleil fixe et sauvage,...(LPH 192)

Pierre and Jacques reinforced each other's perceptions and supported each other throughout their school years together. Having come from the same world, they could easily relate to one another.

At the "lycée" Jacques becomes enamored with the exoticism of a new friend, Georges Didier who shares his interest in French and reading (LPH 190-3). This young man is the epitome of the proper bourgeois French child and as their paths cross, a whole new universe is opened up for Jacques who learns what is an average French family. Didier and his family value their history and their links to France; they have photographs, letters, souvenirs, and stories documenting their past. Didier would quote his father and his grandfather, offering precepts for daily living---a kind of oral tradition that was totally foreign to Jacques. 
An extemely bright boy, Didier came from a family of practicing Catholics. He had been raised with a solid moral grounding and was capable of defending his faith and his conduct. Vulgarity and obscenity never invaded Didier's speech and he persuades Jacques to give up any "gros mots", which he does quite easily but only in his friend's presence.

The gentle Didier's sense of right and wrong, good and evil, God and country appealed to Jacques precisely because Didier's zeal for the absolute was so alien to him. In contrast to Jacques' rudimentary sense of morality which reflects Camus' earlier description of the Algerian man's code (N 87), Didier's seems complex, mysterious and incomprehensible (LPH 192). Jacques grows up knowing some basic rules: one doesn't steal and one defends one's mother and one's wife.

Their friendship is significant because it allows Jacques at a young age to discover that others may see and experience the world quite differently. While Didier's world is enticing, it is a world to which he can never belong. As an adult when he lives in France, he will remain a stranger to the world of family tradition, history, and religion.

Camus uses a colorful metaphor to describe the allure of Didier and the bourgeois tradition that he represents which is countered by the reality of Jacques' strong sense of belonging in Algeria played out in his attachment to Pierre.

Mais le berger kabyle qui, sur sa montagne pelée et rongée de soleil, regarde passer les cigognes en rêvant à ce Nord d'où 
elles arrivent après un long voyage peut rêver tout le jour, il revient le soir au plateau de lentisques, à la famille à longues robes, et au gourbi de la misère où il a poussé ses racines.

Ainsi Jacques pouvait être grisé par les philtres étranges de la tradtion bourgeoise, il restait attaché en réalité à celui qui lui ressemblait le plus et qui était Pierre (LPH 192-3).

Jacques is compared to an indigenous shepherd which suggests both his connection to the land as well as his solitude. Like the shepherd, he is alone contemplating, dreaming, trying to decipher the world only to return to the simplicity and poverty of his family, his real home. Didier's presence, like the exotic migrating birds from the north, evokes all sorts of imaginings about the foreign land. And although Jacques can be seduced by aspects of Didier's tradition, he can only be who he is and thus prefers Pierre with whom he can identify.

The friendship with Didier is highlighted because it contributes to Jacques' formation. It is critical in opening a new world for him and rendering it concrete. In a sense, the France of his earlier school years had been a myth so Didier brings him closer to the reality by giving him an insight into the alien culture. Knowing Didier helps him to better see the uniqueness of his own family and upbringing.

As an adult, Jacques is able to put his past into perspective by isolating the influences on his "éducation sentimentale". He draws upon experiences and memories of individuals who loom large in his memory, exposing their impact through anecdotes and reflection on his feelings. In the process of travelling back in time with the 
narrator, the reader detects an implicit thread of love that connects the adult Jacques to those who shared in his "becoming". 
CHAPTER III

\section{AUTOBIOGRAPHY INLEPREMIERHOMME}

Given the notes accompanying the manuscript of Le Premier Homme, one can easily imagine how Camus' definitive rendition of the novel might look different --- especially how the more obvious autobiographical traces would be disguised. In a number of respects, the contemporary reader can enjoy these colorful and wonderfully detailed scenes from the past as glimpses into what contributed to the formation of the unique personality and thought of Albert Camus.

So true to the fact (with a few minor variations) is the story of Jacques Cormery, that we can classify the text as it exists as autobiographical. Was Camus returning to his roots to work out his own problems with his humble past or was he creating a past and a present for previous characters? Was he paying homage to his origins and at the same time painting a picture for the world of the real ambiguity of Algeria?

According to Pauly, in autobiography, the author's "cradle" always haunts his/her writing. She uses this image to link one's first impressions of life (the rocking and the soothing mother's voice) and its impact on creation. In the text, she claims, a symbolic birth substitutes real birth. There is also an identification with the maternal model in literary creation and in this a futile nostalgia for union with the mother (Pauly 103). 
Like Baudelaire's "centralisation et la vaporisation du moi", the nostalgia for the past is really an obsessional desire to return to the state prior to individuation. "Le texte devient un appel d'amour envoyé à ce destinaire privilegé qu'est la mère, l'être textuel rejoignant ainsi sa source réelle" (Pauly 103). These observations can certainly be applied to Camus' work here as well as the early texts like L'Envers et l'endroit; he is on a quest of sorts that continually leads him back to the mother. As I stated earlier in discussing the mother/son relationship, Camus' protagonist longs for his mother's affection. Although he acknowledges that she loves him, there seems to be something lost in her silence and in her indifference.

The quest for his father takes him on a nostalgic journey to his childhood and to his feelings for his illusive mother. The search for the father is ultimately a search for himself, a piecing together of the missing or unexplored parts of his past and finally his make up. Having reached a level of understanding of his experience, the subject achieves some sense of resolution.

The connections between Le Premier Homme and Albert Camus' childhood demonstrate that the work is autobiographical and thus subject to the writer's perceptions of his personal history. Hewitt, in Autobiographical Tightropes, points out that in Colette's autobiographical work, she takes carefully chosen memories and arranges them artistically rather than trying to recount her entire life. Further, there are no formal guarantees, no pact with the reader that the narrator is, in fact, the author (3). This can be said of 
Camus' attempt to paint the amibivalence of his Algerian childhood. His, too, is an act of reshaping and recreating this familiar material.

Throughout his life, Camus believed that his father's family had come from the Alsace-Lorraine region of France after the FrancoPrussian War. His protagonist in Le Premier Homme also traces his paternal heritage to the same region. According to Jean Grenier, Camus' mentor and friend, Camus did go to Ouled Fayet in search of his father's relatives so he had made an attempt to verify the Camus family's origins. The Algerian authorities did not have the information to give (Lottman 9).

Recent biographers such as McCarthy and Lottman refute the father's alleged Alsatian origins. The "Etat Civil", the French national public records office does have a record of the first recorded Camus. Records show that a Claude Camus, born in 1809 in Bordeaux, immigrated to Algeria early on in the first wave of the French settlement of its colony. His wife, Marie-Thérèse accompanied him. They settled in Ouled Fayet, an agricultural village near Algiers. This account is at odds with what Camus knew and presented in his novel as a brief, general history of his ancestors.

This first Camus couple had a son who was born in Marseilles in 1842. It is speculated that the mother had returned to France to received medical care and possibly to escape the war the French were waging over their conquests against Abd el Kader. Baptiste Camus, says Lottman, is the relative who according to family legend had migrated from Alsace. He would pursue his father's work as a 
farmer in Ouled Fayet and marry a local young woman, MarieHortense Cormery, in 1873. (Hence, we have the name of Jacques' family in the novel.) Her family had come from the Ardèche region in south central France but she had been born in Algeria. These facts firmly establish that there were no links to Alsace-Lorraine on the paternal side of the writer's family (Lottman 9).

Despite this discrepancy, the remaining details of the family's composition and geneology correspond almost identically to Camus' rendition of the Cormery family. First, his father's story matches the novel's account even down to residual resentment his father felt towards his siblings; the adult Jacques gleans this same information in a conversation with his mother. Camus' paternal grand-parents, Baptiste and Marie-Hortense, had five children, the youngest being his father, Lucien Auguste. The child was only a year old when his father died so he was placed in a Protestant orphange by his older siblings, but as an adolescent, he ran away and was able to be placed as an apprentice labourer in a vineyard at Chéraga. Family accounts back up what the character, Jacques' mother, says about the father's bitterness in face of abandonment at such an early age: "Sa soeur l'a laissé. C'est pas bien. II ne voulait plus les voir. ...il leur en voulait" (LPH 63-4). He never forgave them consequently, Camus never knew his paternal relatives (Lottman 16).

On his mother's side, one can easily trace the Spanish origins that parallel the geneology outlined in the novel. Going back to his great-grandparents, who were from Minorca, a Spanish territory, Camus was able to trace their migration to Algeria sometime before 
1850 when his maternal grandfather, Etienne Sintes was born.

Catherine Marie Cardona, Camus' maternal grandmother was born in Minorca near the capital Mahon. Catherine and Etienne married in 1872 and settled in Kouba where Etienne would support a family of nine children. Seven of these children lived to be adults---two of them had auditory handicaps like the two siblings portrayed in Le Premier Homme, Catherine, Jacques' mother and Etienne, his uncle.

Camus biographer McCarthy suggests that the author's identity was based on two significant elements: his pride in his mother's Minorcan origins and his mixed descent like so many Algerians, and his belief that his father's family as Alsatians had chosen to remain French rather than become German when the region came under German control. In the writer's mind, he was authentically French and Algerian (10). This alleged perception sheds light on his later positions regarding the French-Algerian conflict.

In 1907, Lucien Auguste Camus, the writer's father, began his obligatory military service joining the Zouaves to fight for two years during the French invasion of Morocco. On his return, one of his brothers helped him find a job as a wine transporter for Ricome. At this point he met the Sintes family and was taken in by them. In 1909, he married one of the daughters, Catherine, who was three years his senior. Again, these details are preserved in the novel as Jacques' attempts to learn about his father.

The basic illiteracy of the Cormery family which is emphasized as a barrier for Jacques echos the reality of Camus' family. Lucien Auguste Camus was functionally illiterate (he had learned basics in 
the orphanage though the novel credits the father's benevolent Ricome employer with giving him some skills). Camus had several reports in his possession that had been penned by his father and his mother (like Jacques' mother) kept several postcards from her husband. More significantly, both Camus' mother and grandmother, the two women who raised him, could not write as evidenced on Catherine's marriage certificate (Lottman 16).

Although the details and drama of Camus' "first man's" birth might seem to be the stuff of fiction, they are based on the actual circumstances of his own entry into the world. The writer was born at 2 a.m. on November 7, 1913 at the Ferme Saint-Paul near Mondovi. Ricome had offered Lucien Auguste a long-term position in a vineyard and it was immediately following their arrival that his mother gave birth to her second son, Albert, at home in a low whitewashed bungalow (Lottman 17).

When the child was seven months old, his father was again called up to serve in his former regiment in the Zouaves which quickly shipped him off to France on the eve of World War I. Meanwhile, Catherine and her two sons, Albert and Lucien, joined her mother and two brothers in their apartment in the Belcourt section of Algiers. About a month later, she received a reassuring postcard from her husband, followed by news of his being wounded. In October at Saint-Brieuc, two months after his departure, Lucien Auguste died from a head wound (Lottman 18).

The memory of the father is subtly yet reverently preserved in the form of a few souvenirs: the postcards are kept along with the 
pieces of shell that had killed him and his Croix de Guerre and Médaille Militaire are preserved in a frame. Again, Camus has meticulously maintained these details in the fictional screen of the Cormery family.

Camus' mother was forced to work to support her young sons and eventually found steady work as a maid. She was quiet and resigned while her mother directed the household and took over the discipline of her children. Her detachment from the boys as described in several biographies gives an impression of the ambivalence the two children must have experienced; in the novel this is a source of mysterious anxiety for the young Jacques who desperately wants his mother's love.

Throughout his life, Camus remained deeply attached to his mother. Notes in his diary as well as what he said pubicly indicate his attachment. He would rush to her side when she was ill even if it meant flying from France, a real sacrifice for someone who was claustrophobic (Lottman 520).

Uncle Etienne, his mother's semi-mute brother, worked in a cooperage in the neighborhood like his counterpart in Le Premier Hemme. He was mute until the age of 13 or 14 and then was helped by surgery, although he still spoke with difficulty. His truncated speech is duplicated in some of the dialogue in the novel. Albert, his nephew, helped out in the cooperage occasionally; this experience was no doubt the source of the incident in the workshop when Jacques is hurt. Both the uncle and the cooperage appeared in previous works: first in "Les Voix du quartier pauvre", precursor to 
L'Envers et l'endroit, and later in "Les Muets" from L'Exil et le reyaume.

The portrait of the author's grandmother who actually raised him is manifested in Jacques' grandmother. Camus' grandmother dominated everyone in the household; her need for control may have been born from the fact that she had lost her husband and several children and had to fend for herself and for the remaining children. She was a proud and tenacious woman who had definite ideas about child rearing. She strictly enforced her rules and inflicted corporal punishment (whipping with a leather strap) when necessary. Both Albert, his brother, and his mother were under her command.

Catherine Camus was never able to declare her independence from her mother due to her handicap and lack of skills.

The Belcout neighborhood and the Camus-Sintes family apartment are well-depicted in the novel. Belcourt was supposedly largely inhabited by low-income workers of French origin, thus the Sintes, as Spaniards were an exception. Because it bordered a Moslem neighborhood, families from Belcourt had more contact with the Arab population (Lottman 27). Camus' description of the Arabs passing in the street outside the Cormery apartment, the Arabs present at the neighborhood cinema and the children playing in the Arab quarter reflects this fact (LPH 73, 91). As a child Camus lived in a three-room modest apartment without amenities and without decor. The family shared a bathroom, had no running water or electricity and did not own a stove. These details also approximate those presented in the novel. 
Cormey's reminiscences about teachers, friends, soccer, and books also parallel what we know about Camus' childhood experiences. Indeed school must have been another world for the young Camus whose teacher, Louis Germain, in the equivalent of fifth grade, discovered his giftedness. We learn that Germain is the model for Jacques Cormery's teacher, Monsieur Bernard, because Camus uses Germain's name in the text when referring to Bernard. Monsieur Bernard becomes an advocate for Jacques' continuing his education just as Louis Germain did for Camus in real life. The editor's inclusion of the letters Camus exchanged with Germain after the award of the Nobel Prize emphasizes his great affection, admiration and finally his indebtedness toward this man who had clearly become a surrogate father. In the letter, Camus states that upon receiving the award he had thought immediately of his mother and then of Germain, his "other parent" (LPH 327). Indeed the text conveys the sentiments expressed in the letters.

André Villeneuve, Camus' classmate who also went on to the "lycée" with him, is represented in the novel by Pierre. The two friends read and played together. Another friend, Georges Didier (Camus uses his real name in the text), from the "lycée", began a small literary magazine to which Camus contributed. Later, Didier became a Jesuit. The corresponding character in the novel is Jacques' window into bourgeois culture and Catholicism.

The writer's enthusiam for soccer is well-documented. When his friend, Charles Poncet, asked him if his poor health had not been a factor and he had had a choice, what he would have pursued: 
theater or soccer. Camus' response was "soccer, without hesitation" (Lottman 41). That zeal is also communicated in his protagonist's willingness to lie (which we are told is out of character) to be able to keep his grandmother's change in order to have enough money to see a soccer match (LPH 86).

Camus did work at various jobs before establishing himself as a writer. The summer jobs described in Le Premier Homme are based on real experiences but are drawn from a later period when he had to support himself (Lottman 79). For example, Camus did work as a ship chandler in 1935 after he was married to Simone Hié (Grenier 20).

Had Camus lived to finish his novel, he would have also written about Jacques Cormery's adolescence as his notes indicate a second part of the novel entitled "L'Adolescent". And if it had been based on his own adolescent years, he would have no doubt written about the inspiration of Jean Grenier who became his first mentor, and also his first attack of tuberculosis which occurred when he was only 17. According to McCarthy, Greniers's work, "Les lles", helped guide him to develop several ideas. First was the revelation that the amputation of his illness and the silence of his home were important experiences and secondly, that the Mediterranean beaches might offer more than just physical pleasure (McCarthy 22).

The evidence of so many details obviously drawn from Camus' personal experience proves that Le Premier Homme is largely autobiographical. In a very personal way, Camus further 
substantiates what he had revealed of himself in previous texts and opens the door to understanding the shaping of his unique vision. 


\section{CHAPTER IV}

\section{STYLE}

Le Premier Homme contains a range of elements whose influences can be traced from the eighteenth century to nineteenth century Romanticism and Realism. We can also identify passages that resemble the Nouveau Roman for which Camus was a precursor. The Romantic elements are found in the theme of communion with nature, the correspondence between nature and humanity and the focus on the self and on feelings. The universe for Camus is like that of Chateaubriand: "une divinité immense" which corresponds to one's inner world, awakening profound emotions. Rather than just suggesting emotional states, Camus gives them a name and often describes the physical sensation associated with a feeling.

Several passages in the text reflect Balzacian qualities in a brand of realism where there is a harmony between the decor and its inhabitants. For example, the description of the Cormery apartment reflects in its sparseness and simplicity the same austerity of the adults---their intellectual lack, and the economy of their lives of silence, lives reduced to working, eating, sleeping, simply surviving. Similarly, the dimly lit office that smells of iron where Jacques is forced to spend his summer working in a meaningless job corresponds with his boredom. From the solitary window, he could only the see streets and the buildings across the street; the sky was not visible. Thus, without the sun and the sky, without light and the 
open horizon, "une lumière s'éteignait en lui" (LPH 244). The depressing environment manifests Jacques' state of mind.

Camus' description of the room where Jacques is born is done with the objective eye of a camera not unlike the descriptions found in the Nouveau Roman. The position of each piece of furniture, the mattress and covers, the placement of the luggage are precisely recorded. Even the women in the room are described as part of the decor; they are nameless and are only characterized by their actions (LPH 21).

In Le Premier Homme, the compelling narrative is told from Jacques Cormery's point of view by a narrator who is both witness and participant. As a witness, the narrator offers a moralizing voice that resembles that of the narrator in L'Envers et l'endroit. The narrator renders an intimate portrait and occasionally offers commentary in the form of an aphorism reminiscent of one of Camus' favorite eighteenth-century writers, Nicholas de Chamfort. (Camus had written an introduction to Chamfort's Maximes.) For example: "La misère est une forteresse sans pont-levis" (LPH 138) and "Le temps perdu ne se retrouve que chez les riches. Pour les pauvres, il marque seulement les traces vagues du chemin de la mort" (LPH 79).

In Jean-Paul Sartre's "Explication de L'Etranger", he linked Camus to the classical tradition, placing him in the great lineage of "moralistes français" (Sartre 142). This novel, though much less philosophical, uses some of the tools of the "moralistes". While quite divergent in style from earlier works, the reader can make some comparisons. 
The ornate style here is enriched by a repetition of themes and motifs, and a use of irony and paradox frequently found in Camus' work. An examination of themes in Chapter I demonstrated that some of the prominent themes and motifs in his work as a whole are critical in Le Premier Hemme. One can locate, for example, such themes as silence, the "stranger/outsider", the mother/son relationship, and poverty. In addition, we find common Camusian leitmotivs: the sun, the sea, the silent mother, and the father witnessing the execution. Lottman, the most recent Camus biographer, who had access to the yet unpublished version when he was writing his book, compares the lyrical style to that of the American writer, William Faulkner (692). Indeed, not only the poetic prose but also the complex syntax resembles Faulkner's writing. Contemporary readers have no way of knowing if or how much Camus would have retained of this seeming experiment.

Irony is another trademark of Camus. One of the principal ironies treated in this text is the irony of the "père cadet". Jacques Cormery, at forty, visits his father's grave and suddenly realizes that he is older than the father when the father was killed. He actually had more life experience than the young man who was in the grave; Jacques could have been the father of a man his deceased father's age. He thirsts to know more about the identity and the history of this "stranger" who was his father but there is little to learn because of the brevity of his life. The absurdity and injustice of the situation triggers anguish and pity in the aging man (LPH 30). 
Another example of irony is found in the account of the French immigrants who came on the "Labrador" expecting to find a "promised land" in Algeria. The irony in the ship's name lies in its evocation of a cold, northerly land when it is transporting the colonists south: "...pour aller vers les moustiques et le soleil"(LPH 173). Then in reverse irony, the ship and its passengers end up sailing through a horrible winter storm before disembarking in the harsh, hostile land they would call home.

When the adult Jacques visits his mother, she takes up her familiar position at the window watching the passersby. On this particular Sunday morning (an intertextual allusion to Meursault's weekend pasttime), an Arab family is going by and one of the children, a small boy is dressed up as a French paratrooper. At the same moment a patrol of paratroopers also comes down the street. The boy symbolizes the pro-French Arabs who have accepted French rule; he mimics the very men who represent France. As the patrol passes in front of the Cormery apartment, a bomb explodes down the street. The image of the Arab boy dressing in a French uniform suggesting admiration, acceptance and cooperation is juxtaposed with the presence of the terrorists in the same street which suggests resistance, conflict, and violence. A second irony in this situation is this attack that occurs in the presence of those who are to protect the population. In the Camusian vision, paradox and a constant preoccupation with ambiguity, his notion of "l'envers et l'endroit", are prevalent. The whole of Jacques' reminiscences depict "une enfance misérable et heureuse" (LPH 127). Camus' 
conception of "l'envers et l'endroit" creates a balance by exposing ambiguity in the world; it gives his images a unity and a reality that rings true to the reader. In spite of the poverty both physical and emotional, he knows that he experienced contentment.

The reader glimpses the narrower history of the family in addition to the history of the colonization of Algeria in which Camus exposes both sides---the best and the worst of humanity. Confronted with the larger human world, Jacques views history as "affreuse et exaltante" (LPH 182). Throughout the novel, the narrator points out the ambiguity of Algeria: its harshness and its warmth, its hope and its despair, its misery and its richness. Jacques Cormery is attached to "...cette terre splendide et effrayante..." (LPH 258), a land that offers as many splendors as horrors in nature and in the people.

The writer also uses qualifiers that juxtapose two terms in order to reflect the ambiguity of Jacques' world. For example, the Arabs are a "...peuple attirant et inquiétant, proche et séparé" (LPH 1179). They are present and yet distant, attractive, yet disturbing.

As an adult, Jacques' ontological musings lead him to observe that in Africa (referring to North Africa), people (referring to the "pied-noirs") lived with the pain of knowing their existence in Algeria would not last and that they risk being forgotten like their ancestors had been.

... des trois hommes qui reprenait le chemin du village le coeur serré par l'approche de la nuit, plein de cette angoisse qui saisit tous les hommes d' Afrique lorsque le soir rapide 
descend sur la mer, sur les montagnes tourmentées et sur les hauts plateaux, la même angoisse sacrée que sur les flancs de la montagne de Delphes où le soir produit le même effet, fait surgir des temples et des autels. Mais, sur la terre d'Afrique, les temples sont détruits, et il ne reste que ce poids insupportable et doux sur le coeur. Oui, comme ils étaient morts! Comme ils mourraient encore! (LPH 179)

The "temple" metonomy, describing the men's anguish at dusk in this land without "temples" refers to their lack of attachment to the concept of a Delphic oracle, prophets who could unveil a future which may not exist. Destiny was destiny---their were no Greek gods to whom they could appeal. These people do have a consciousness about death which is simultaneously unbearable and agreable; it is unbearable to face one's inevitable death, to know one is subject to oblivion, nevertheless, this consciousness is freeing, and therefore the burden is tolerable.

Besides reflecting ambiguity, the imagery in Le Premier Homme emphasizes Jacques' exuberance for life. In an exaltation of the senses, the writer evokes the sensate world of Jacques' childhood. What particularly stands out is the frequency of olifactory memories. The vivid visual and tactile descriptions throughout the text regularly include smells. (Jacques seems to have inherited his uncle's highly developed sense of smell.)

These smells are pleasant and are usually associated with some of what Jacques cherishes most: his mother, nature, and school. He remembers "la douce odeur" of his mother's skin which he calls 'l'odeur de la tendresse" (LPH 58). Smells from nature are also abundant in the text: "l'odeur des fleurs mouillées", "la senteur 
salée" (LPH 29), "l'odeur des oranges" (LPH 135), "l'odeur

d'embrun" (LPH 124), "l'odeur de la terre mouillée" (LPH 239), and "l'odeur des seringas et des magnolias" (LPH 207). As a grown man, Jacques still dreams of the earthy smells of the neighborhood stables: "l'odeur du crottin, de paille, et de sueur qui venaient de ces lieux interdits dont Jacques rêvait avant de s'endormir" (LPH 51). The beauty and adventure of school are enhanced for Jacques by its unique smells: "l'odeur de vernis des règles et des plumiers, "...de l'odeur amère et rèche d'encre violette" (LPH 137). In class, when he is chosen to fill the ink pots, he gleefully smells the mouth of the dispenser bottle. He also relishes "une bonne odeur d'imprimerie et de colle" in books (LPH 137).

In one instance, a smell triggers a creative association born from the boy's active imagination:

...les jours de pluie enfin, de cette odeur de la laine mouillée qui montée des cabans de laine au fond de la classe et qui était comme la préfiguration de cet univers édénique où les enfants en sabots et en bonnet de laine couraient à travers la neige vers la maison chaude (LPH 137).

The smell of wet wool evokes the exotic, "perfect" world of France, the world idealized by the child and reinforced by his schoolmaster.

A profusion of olifactory memories, from infancy to adolescence, flood his consciousness (an entire page at the end of the text) accentuating the intensity of Jacques' passion for life and his sensuality (LPH 258-60). And, on several occasions in the text, the author uses olifactory images in combination with other senses 
such as taste and vision to create synesthesia---images with more depth.

For example, "le bureau sentait le fer et l'ombre" combines smell and sight, and "l'air goût de sel" combines smell and taste, evoking the sea.

A discussion of memory and sensory associations in this novel inevitably includes Proust. Camus' protagonist does conjure up some of his memories by pure mental association, however on several occasions, like Proust eating his madeleines, he finds that the permanent images in his memories are connected to sensory associations. During Jacques' passage by ship back to Algeria, the sweltering heat, and the predicament of having to retire to his cabin for a nap brings his grandmother's voice to the surface of his consciousness and he is immediately propelled into the past, into her presence. "A benidor", her call for nap time summons bittersweet memories of imprisonment, boredom, and frustration (LPH 41). Later, the smell of his mother's neck, "l'odeur de la tendresse", evokes memories of the moments when he had enjoyed her affection; when he had sat on her knees and slept with his arms around her neck (LPH 58). Surrounded by his memories, Jacques questions their validity: "...il n'était pas sûr que ces souvenirs si riches, si jaillissants en lui, fussent vraiment fidèles à l'enfant qu'il avait étén (LPH 127).

Although Camus' use of simile in the text is limited, it is interesting to note that he uses comparisons with nature when employing this stylistic device: 
"La guerre était comme un vilain nuage" (LPH 69), "...un souvenir impalpable comme les cendres d'une aile de papillon brulée dans un incendie de forêt" (LPH 73), "...il coulerait comme une pierre" (LPH 97). Again humanity's experience is juxtaposed with the indifference of the natural world. 
CHAPTER V

\section{CAMUS' VISION REFLECTED IN LEPREMIERHOMME}

Albert Camus' artistic and philosophical vision has definite roots in his early life when he was growing up in French Algeria. Many of his ideas appear to originate in the experiences of his youth. Critics like McCarthy have in the past contended that Camus' vision is more autobiographical than it seems. McCarthy says: "...he tried to make his books objective but they all lead back to him" (9). If we accept the premise that Le Premier Homme is autobiographical, then we can trace many of his ideas to the experiences of his youth depicted in the novel. His empathy for the proletariat, his exaltation of the Mediterranean, his attitudes towards life, the seeds of Le Mythe de Sisyphe, and the notion of "l'etranger" (the stranger/outsider) are all nascent in the "enfance miserable et heureuse" (LPH 127) of Jacques Cormery, Albert Camus' stand-in. Also, the ambiguity that so often characterizes Camus' work is captured in the portrait of this protagonist. In spite of the fact that the portrait of the adult Jacques is incomplete, the reader detects the contradictory nature of a man who is both humble and proud, successful but disdainful of his success, and abstemious but pursuing women.

Both in relationships with his family and in his status as a French citizen, the main character is surrounded by ambiguity. He 
has a mother but his grandmother raises him. He senses at times his mother loves him, and yet, she seems so detached. Finally, interpretation of her love is fraught with ambiguity; he concludes that she loves him by her looks and her telling others that he is a good and intelligent boy.

On the occasion of the opening of La Maison de la Culture in Algiers in 1937, Camus gave a lecture on what he called "the new Mediterranean Culture". He suggested that people express themselves in harmony with their land and that the word "country" is not an abstraction related to a nationalist view of sending men off to war, but rather a certain way of appreciating life that is shared by certain people (LCE 191). His own work is an example of this harmony in which he articulates an experience of the French Algerian.

The land and its people, the "second" subject of Le Premier Homme have their own story which uncovers aspects of the Camusian vision. In Noces, the author speaks of the harmony and silence that exist between people and the world which engender a love that he shared with "a whole race born in the sun and sea" (Essais 72). This image of a quasi-mythical people reveals Camus' conviction that his people are their own gods, so to speak, inhabiting a land where they have everything that they need: "the sea, visible from every corner, a certain heaviness of sunlight, the beauty of the people" (72).

Given this previous image, it is useful to see how the writer specifically presents his people in the novel. Jacques, like Camus, 
is part of this unique race who experiences "la naissance et la baptême dans la mer" (LPH 256), the domination of the sun and the indifference of the natural world. As Jacques ponders the history of his ancestors' immigration, he remarks their courage and tenacity in spite of the odds against them. In Chapter 7 ("Mondovi; la colonisation et le père"), he enumerates their trials and suffering by describing the horrible five week trip by boat, and the arrival in a strange, unwelcoming land where without roofs over their heads, they braved the pelting rain, followed by a cholera epidemic exacerbated by the unbearable heat.

Indeed, these first "pied-noirs" encountered hostility from all sides: la garde veillaient pour défendre les assiégés contre les lions à crinière noire, les voleurs de bétail, les bandes arabes et parfois aussi les razzias d'autres colonies françaises qui avaient besoin de distraction ou de provisions. (LPH 176) Yet, despite the deaths, the on-going threat of insurrection, and the general insecurity, they continued to look towards the future. The struggle may be hopeless but they choose, as Sisyphus does, to go on. Jacques' parents represented the second generation of these people.

In Neces, Camus writes about the workers of Algiers who are not guilty of hoping for another life, thus escaping the greatness of their own lives (Essais 91); this acceptance of one's situation is found in Jacques' mother (closely mirroring Camus'). Her silent resignation, though problematic on an emotional level, becomes a source of admiration. The mother, a poor, lonely widow with two children, burdened by her back-breaking work as a maid, becomes one of the writer's early models for Sisyphus. 
...elle endurait pour elle-même la dure journée de travail au service des autres, les parquets lavés à genoux, la vie sans homme et sans consolation au milieu des reliefs graisseux et du linge sale des autres, les longs jours de peine ajoutés les uns aux autres pour faire une vie qui, à force d'être privée d'espoir devenait aussi une vie sans ressentiment d'aucune sorte... (LPH 61)

She, like those before her, toils day after day without complaining; biographers tell us that Camus witnessed this same ethic in his own mother. It is this struggle without hope and without resentment that Camus came to admire. The mother lives in reality; she refuses to replace reality with illusion by refusing to hope for another life. Jacques' reflections on his father's life paint another courageous character, probably like so many young Camus knew in his own working class neighborhood and had described in his essay "L'Ete à Alger" (N 86). The father had had an entirely involuntary life, making his way obstinately although without the lucidity that Camus proposes in Sisyphus:"...depuis l'orphelinat jusqu'à l'hôpital, en passant par le mariage inévitable, une vie qui s'est construite autour de lui, jusqu'à ce que la guerre le tue et l'enterre" (LPH 179). The idea that one can stoically accept whatever life brings and move beyond what he calls in L'Envers et l'endroit "l'envie, le véritable cancer des sociétés et des doctrines" (15) is part of the premise of Le Mythe de Sisyphe.

Camus once told a critic that he learned freedom in poverty rather than from Marx (Lottman 36). This statement reveals not only the nostalgia for his Algerian childhood, but to the attitudes he absorbed and lessons he learned while growing up in poverty. One of 
these is the ability to live in the present, taking each day as it comes because each day for the poor simply involved surviving. For the children, Jacques and Pierre, a future life seemed inconceivable because life in the present seemed inexhaustable: "tant la vie présente leur paraissait inépuisable chaque jour sous la protection des divinités indifférentes du soleil, de la mer ou de la misère" (LPH 192).

Jacques finds his elderly mother and uncle even more grounded in the present: "ils vivaient maintenant dans la proximité de la mort, c'est-à-dire, toujours dans le présent" (LPH 127). This is the attitude espoused by Camus in Le Mythe de Sisyphe; we must live in the present as this is our only certainty.

Another lesson of poverty is manifested in the adult Jacques' detachment from materialism. This is a freedom that comes from having had few possessions, thus never becoming attached to objects. His valuables are freely offered and easily possessed; what he considers as riches are the riches that are available in the natural world. Jacques demonstrates his love for Malan and his nonmaterialistic sensibility in the sincere proposition he makes to his friend; he tells him that he could easily give him all his worldly possessions (LPH 38).

Two haunting images from Jacques' childhood, the grandmother in her long black dress and the story of the father going to the execution, as previously discussed, are autobiographical and appear to have influenced Camus. Jacques has a feeling of being judged at school, but the grandmother's pronouncements terrify him. These 
autobiographical anecdotes may account for Camus' horror of judgement and especially the death penalty which extended into his opposition to killing for a cause. Camus will never support the terrorist tactics of either side in the Algerian conflict. In the novel, the French Algerian worker who verbally attacks the Arab tells Jacques that all of the Arabs had to be killed (LPH 75); his voice is like the voices of Nazism and Stalinsim, two systems that legitimized killing, two systems that Camus vehemently opposed.

As the conflict between nationalists in Algeria, represented eventually by the FLN (le Front de Libération Nationale) in 1954, and the French government worsened after World War II, Camus was unable to take sides, though for a time he was outspoken about his own perspective and solutions. In Le Premier Homme, he sets out to give some insight into the complexity and ambiguity of the situation with a bit of the history of his people, the "pied-noirs". We read his concern for the escalating violence and a desire to preserve a sense of fraternity between both peoples.

Jacques loves Algeria as his own, but in a sense, it is not his land. The Arabs' presence fuels this ambiguity. A vague unspoken threat in their very presence contrasts with the security of his family. By speaking for the first French settlers and their ancestors, who like Jacques have bonded with Algeria, Camus shows us how they also are connected to the land they call home. In the writer's mind, they are not oppressive or exploitive; they are just trying to survive. 
Camus speaks for his family and for their forebears, those who risk being seen only as "colonizers", those whom the government was ready to abandon in the late fifties. The history of these "first men" helps to clarify their attachment to their adopted land. The reader empathizes with this population that doesn't belong in France and is alienated from the place they call home. Working and living side by side with the indigenous population, the working class "piednoirs" remain separate and live with the festering, silent threat of revolt. The writer captures the foreboding atmosphere in the passage where Jacques describes staying as a child at his aunt's rural home where she checks to be sure that the windows are secured:

...avec autour de lui ce peuple attirant et inquiétant, proche et séparé, qu'on côtoyait au long des journées, et parfois l'amitié naissait, ou la camaraderie, et, le soir venu, ils se retirait pourtant dans leurs maisons inconnues, où l'on ne pénétrait jamais, barricadées aussi avec leurs femmes qu'on ne voyait jamais ou, si on les voyait dans la rue, on ne savait pas qui elles étaient, avec leur voile à mi-visage et leurs beaux yeux sensuels et doux au-dessus du linge blanc, et ils étaient si nombreux dans les quartiers où ils étaient concentrés, si nombreux que par leur seul nombre, bien que résignés et fatigués, ils faisaient planer une menace invisible qu'on reniflait dans l'air des rues certains soirs où une bagarre éclatait entre un Français et un Arabe... (LPH 257)

The inhumanity that is portrayed in Camus' brief rendition of the historical tension is recognized as part of the human condition (LPH 177); both sides are guilty of extreme barbarity. Graphic descriptions of the multilations serve to emphasize the horror and the reality of the violence. The characters Henri Cormery, Uncle 
Etienne/Ernest's friend Daniel, and the old doctor are voices that name the violence; Henri Cormery and the old doctor speak out against it (LPH 66, 140, 177).

Regarding the conflict, the character of Veillard proposes that some of the "pied noirs" are so attached to the land that they are ready to die for it. They are convinced that there will eventually be a solution. "On ne comprend pas ça à Paris" says Veillard (LPH 168), but Camus wants the world to understand. Veillard maintains that the Arabs actually understand them by the simple fact of their underlying kinship:

On est fait pour s'entendre. Aussi bêtes et brûtes que nous, mais le même sang d'homme. On va encore un peu se tuer, se couper les couilles et se torturer un brin. Et puis, on recommencera à vivre entre hommes. C'est le pays qui veut ça... (LPH 168-9)

While he believes in the brotherhood of all men and the possibility of a compromise between the two peoples who each claim sovereignty in Algeria, the writer never accepts the vengeful violence which has become habit.

Jacques' actions after the bomb attack near his mother's apartment are indicative of Camus' public call for fairness and for the preservation of fraternity between the two peoples. His protagonist intervenes in a potential lynching when an Arab is cornered by an angry French Algerian after the bombing. Jacques removes the Arab from the situation finding him security in his friend Jean's café. After providing sanctuary for the Arab, Jacques reminds the vociferous" pied-noir" who had been harassing the Arab 
that he was speaking and acting out of anger, and that he must think about his words. In the midst of the fear and suspicion triggered by the attack, in a potentially volatile situation where revenge is likely, Camus offers a voice of reason (LPH 74-5).

Camus imagined an independent Algeria shared by both races. He opposed uprooting over a million French Algerians because it would signify the death of Algeria (Essais 1013). Le Premier Homme reinforces Camus' claim on Algeria by the "pied-noirs" who had what he called "des racines séculaires" (Essais 897). Because the writer believed that his own ancestors were among the political exiles from Alsace, he identified with the plight of French Algerians who had adopted Algeria and then risked being expelled. Camus did not live to see his country dismembered; unfortunately, his prophesy of the inevitable demise of Algeria seems to still be playing itself out given its current political and social situation.

Returning to Algeria, seeing the violence, Jacques is concerned for his mother's safety. They witness the bomb attack together and Jacques is prompted to urge her to return to France with him. When he reflects on the horrible scene of the pregnant woman who is disemboweled and mutilated, his thoughts return to his mother (LPH 177). For Camus, she is his ultimate concern. One of his rare public statements on the Algerian conflict around the time of his receiving the Nobel Prize elucidate his position:

J'ai été et suis toujours partisan d'une Algérie juste, où les deux populations doivent vivre en paix et dans l'égalité. J'ai dit et répété qu'il fallait faire justice au peuple algérien et lui 
accorder un régime pleinement démocratique (...). J'ai toujours condamné la terreur. Je dois condamner aussi un terrorisme qui s'exerce aveuglement dans les rues d'Alger par exemple, et qui un jour peut frapper à ma mère ou ma famille par exemple. Je crois à la justice, mais je défendrai ma mère avant la justice (Essais 1881-2).

Such a stance shows that Camus was not a spokesperson for colonial France. He had always tried to diminish the gulf between both groups; he pleaded for both sides. But while he advocated the end of colonial status for Algeria, a peace conference, a formation of a state with Switzerland as its model (Lottman 623), the safety of his loved ones and other innocents was at the heart of his concern. In this speech his mother is a powerful symbol of the victims for whom Camus demands justice.

Jacques Cormery, like his creator, abhors the violence which is being perpetrated by both sides. Consequently, we don't see him taking sides; we do know that he desires peace, and is ready to defend and protect the innocent---especially his mother---just as any good French Algerian man would do. For this stand and his silence, Camus was criticized, particularly by Sartre. 


\section{CONCLUSION}

Camus' last unfinished work offers the reader quintessential Camus as well as a new facet of the writer's artistic production in the form of a very personal, traditional novel. While treating many of the themes from previous work, he creates striking human portraits and employs an effusive style, demonstrating his artistic range. The novel's universality lies in its thematic treatment as well as in its ability to capture the innocence of childhood and the history of one man and his people. In earlier work, Camus confronted the large questions of human existence but in this last novel the protagonist's conflict revolves more around questions of identity. His approach is to personalize the protagonist by giving him a past and exposing his reflections on his experience as he struggles to understand who he is. The author's "Notes et plans" in "Annexes", printed in conjunction with the text, reveal that he had planned to develop the adult Jacques' character, especially his weaknesses and the "darker" side of his personality.

When Jacques Cormery begins his quest for his dead father, he undertakes a journey of self-discovery that permits him to reflect on his origins---the role of the adults in his life, the role of the "pied-noir" culture, and the history of these "first men". His journey does result in resolution; Jacques finds a sense of identity and peace by coming to terms with who he is and where he comes from. He realizes that in the depths of his soul he has a mysterious, vague hope which gives him the courage to accept aging and dying. 
Like a modern Adam in the Garden, Camus' "first man" is surrounded by the splendors of Algeria. He "participates in his natural milieu" as East says of Camus' own growing up (73). The resulting harmony between Jacques and his natural surroundings is an orientation towards "being" rather than "having" (East 73). This attitude gives birth to an instinctive "joie de vivren"(so evident in the character of the boy) which is owed to his humble "pied-noir" roots.

The process in which the self-banished Jacques Cormery seeks the identity of a father who was never quite real for him becomes a process in which he begins to integrate his own identity. Investigating his father's life leads Jacques to the story of his ancestors, his real connection with Algeria, and to his own history which is inextricalbly tied to his North African roots.

Jacques' world is quite realistic in that it is replete with ambiguity. This ambiguity is perhaps most critical as it relates to love in the child's primary relationships. Camus goes straight to the core of what is fundamentally human: a need to love and be loved. First is the case of the absent father; he is a mystery to Jacques and yet now, at forty years of age, he realizes his latent desire for his father's love and guidance. While growing up, he never has a clear image of his father and can never know his love. Surrogate fathers replace the unknown one, nevertheless, the adult Jacques now attests to the lack he feels. Thus, Jacques fixes his attention on his mother whom he desperately loves. This is the ultimate irony of the character's quest: he seeks his father which brings him to his 
precious mother. Over time he has learned to live with her detachment, recognizing her unexpressed love for him, and comes to terms with their minimal communication. Given the mother's silence and passivity and the grandmother's domination, Jacques' mother is essentially a stranger to him as a child. In spite of this, he is lucid enough to recognize the gifts of his childhood and the love he has known.

The character of Jaques' mother, Catherine Cormery, stands out in her simplicity and ignorance; she is clearly venerated for who she is. The writer highlights her Sisyphean qualities and her indifference is seen as a kind of self-preservation. In the adjoining "Annexes" section, Camus had noted that the mother was to be a Christ figure (LPH 283,295$)$. In this light, we see a woman whose life is not her own in many ways, and yet, she accepts her sacrifices courageously and silently.

Her image surfaces throughout the narrative constructing a subtext for the unresolved feelings surrounding her. Although they are very close and Jacques seems to have reached an understanding and an acceptance of the relationship with his mother, something is missing---they do not really know one another. Again the "Notes et plans" reveal where Camus might have taken this; he intended to include a scene where Jacques would try to reveal himself and ask for his mother's pardon for leaving his homeland and for not previously seeing the simple truths of her existence (LPH 273, 319). 
The writer pays tribute to his mother in both the text and its dedication. This coming of age tale focuses on Jacques' love and devotion to his mother. And true to form, Camus' dedication reflects the irony of his unique situation as a Nobel Prize winner whose mother is illiterate. It reads: "A toi qui ne pourras jamais lire ce livre" (LPH 11). It is addressed to "Intercesseur: Vve Camus". How beautiful and terribly sad to dedicate one's writing to another who would never be able to read it. On the pages of this final work, his mother will, ironically, in her silence, speak for her son while he in turn attempts to speak for an endangered people, the working-class "pied-noirs". 
WORKS CONSULTED

Amoia, Alba. Albert Camus. Now York: Continum, 1989.

Barthes, Roland. Le Degré zéro de l'écriture. Paris: Editions Gautier, 1964.

--.. Le Plaisir du texte. Paris: Seuil, 1973.

Brée, Germaine. Camus. New Brunswick: Rutgers UP, 1961.

Camus, Albert. Carnets 1 . Paris: .Editions Gallimard, 1962.

---. L'Envers et l'endroit. Paris: Editions Gallimard, 1958.

-.-. Essais. Paris: Editions Gallimard, 1965.

--. L'Etranger. Paris: Editions Gallimard, 1942.

-.-. L'Exil et le royaume. Paris: Editions Gallimard, 1957.

--.. Lyrical and Critical Essays. Ed. Philip Thody. Trans. Ellen Conroy Kennedy New York: Vintage Books, 1970.

--.. Noces suivi de l'Eté. Paris: Editions Gallimard, 1950.

-.-. La Peste. Paris: Editions Gallimard, 1947.

--.. Le Premier homme. Paris: Editions Gallimard, 1994.

Campbell, Joseph. The Here with a Thousand Faces. Princeton: Princeton UP, 1973.

Costes, Alain. Albert Camus et la parole manquante: étude Rsychanalytique. Paris: Payot, 1973.

Crochet, Monique. Les mythes dans l'oeuvre de Camus. Paris: Editions universitaires, 1973.

Cruickshank, John. Albert Camus and the Literature of Revolt. London: Oxford UP, 1959.

Daunais, Isabelle. "L'expérience de l'espace dans les nouvelles de Camus." The French Review 67 (1993): 47-50. 
Dunwoodie, Peter. Camus: L'Envers et l'endroit and L'exil et le Reyaume. London: Grant \& Cutler, Ltd., 1985.

Eagleton, Terry. Literary Theory: An Introduction. Minneapolis: University of Minnesota Press, 1983.

East, Bernard. Albert Camus ou lhomme à la recherche d'une morale. Montréal: Edition Bellarmin, 1984.

Fitch, Brian. Albert Camus 10: Nouvelles approches. Paris: Lettres Modernes Minard, 1982.

---. The Narcissistic Text: A Beading of Camus' Fiction. Toronto: University of Toronto Press, 1982.

Gay-Crosier, Raymond, ed. Albert Camus 1980. Gainsville: UP of Florida, 1980.

--.. "Albert Camus 14: Le texte et ses languages". Revue des Lettres Modernes. Paris, 1991.

Grenier, Roger. Albert Camus, Soleil et ombre. Paris: Gallimard, 1986.

Hewitt, Leah Diane. Autobiograhical Tiahtropes. Lincoln: UPof Nebraska, 1990.

King, Adèle. Camus. New York: Barnes \& Noble, 1966.

--- Camus' Stranger Fifty Years On. New York: St. Martin's, 1992.

Knapp, Bettina. Critical Essays on Albert Camus. Boston: G.K. Hall and Co., 1988.

Lazere, Donald. Ihe Unique Creation of Albent Camus. New Haven: Yale UP, 1973.

Lapaire, Pierre. "Un style polarisé: éléments de la binarité stylistique chez Camus." The French Review 66 (1993): 607 15. 
Mailhot, Laurent. Albert Camus ou l'imagination du desert. Montreal: Presses de l'Université de Montréal, 1973.

McCarthy, Patrick. Albert Camus the Stranger. Cambridge: Cambridge UP, 1988.

---. Camus: A Critical Study of His Life and Work. London: Hamilton, 1982.

Mino, Hiroshi and Paul Viallaneix. Le Silence dans l'oeurre d'Albert Camus. Paris: Corti, 1987.

Nguyen-van-Huy, Pierre. La Metaphysique du benheur chez Albert Camus. Neuchatel: Editions de la Baconnière, 1968.

Palumbo, Donald. "The Crisis of Faith, Father-Son Ruptures, and Alienation-from-the-Self: Their Interconnection in the Works of Sartre and Camus."CEA Critic 44.3 (1982): 12-17.

Pauly, Rebecca M. Le Berceau et la bibliothèque: le paradoxe de l'écriture autobiographique. Saratoga: Anma Libri \& Co., 1989.

Peterson, Carol. Albert Camus. New York: Frederick Ungar Publishing Co., 1978.

Peyre, Henri. The Contemporary French Novel. New York: Oxford UP, 1955.

Quilliot, Roger. La Mer et les prisons: essais sur Albert Camus.

Paris: Gallimard, 1970.

Rea, Joanne E. "An Artistique and Autobiographical Coincidence in Camus and Joyce." Remance Notes 23.3 (1983): 210-16.

Reichelberg, Ruth. Albert Camus: Une Approche du Sacré. Paris: A.G. Nizet, 1983.

Rhein, Phillip A. Albert Camus. New York: Twayne Publishers, 1969.

Rizzuto, Anthony and David Ellison. "Understanding Albert Camus". The French Review 65 (1993): 825-7. 
Robert, Paul. Le Petit Robert: Dictionnaire Alphabétique \&

Analogique de la Lanque Française. Paris: Dictionnaires Le Robert. 1990.

Sartre, Jean-Paul. "Explication de l'Etranger." Situations 1 . Paris: Gallimard, 1975.

Shabbaz, Caterina, "L'Absurde Jeu Stylistique d'Albert Camus." Symposium 44.2 (1990): 114-126.

Showalter, English, Jr. Exiles and Strangers: A Reading of Camus' Exile and the Kingdom. Columbus: Ohio State University Press, 1984.

Sterling, Elwyn. "A Story of Cain: Another Look at 'L'Hôte'." The French Review 54.4 (1981): 524-29.

Stolarski, Robert. Camus et la Méditerranée. Poznan, 1979.

Sutter, Judith D., and Germaine Brée, eds. Essays on Camus' Exile and the Kinodom. University Miss: Romance Monographs, 1981.

Tarrow, Susan. Exile from the Kingdom: A Political Rereading of Albert Camus. University of Alabama Press,1985.

Thody, Philip. Albert Camus 1913-1960. London: Hamish Hamilton, 1961.

Tremblay, V.-L. "La structure mytho-rituelle de l'imaginaire camusien". The French Review 62.5, (1989): 783-92.

Viallaneix, Paul. Le Premier Camus suivi de Ecrits de jeunesse d'Albert Camus. Paris: Gallimard, 1973.

Withycombe, E.G. The Dictionary of Enalish Christian Names. Oxford: Clarendon Press, 1977.

Zyla, Wolodymyr and Wendell Aycock, ed. "Albert Camus' Literary Milieu: Arid Lands": Proceedings of the Comparative 
108

Literarture Symposium, Jan. 22-5, 1975, Vol.VIII. Lubbock:

Texas Tech Press, 1976. 


\section{APPENDIX A}

\section{CHAONOLOGY}

[The data for this chronology was compiled from the works of Alba Amoia and Roger Grenier.]

1809 Birth of Albert Camus' paternal great-grandfather, Claude Camus, in Bordeaux. Camus' maternal great-grandfather, Miguel Sintès, had been born in Minorca. (Both immigrated to Algeria.)

1913 Albert Camus born to Lucien and Catherine Camus at 2 a.m. at the Ferme Saint-Paul, Domaine du Chapeau de Gendarme, near Mondovi.

1914 Lucien Camus is called up to serve in his former regiment. He leaves his position with Ricôme, wine dealer and shipper and is sent to fight in France. Catherine Camus and her two sons relocate to Algiers where they live with Camus' grandmother in Belcourt, a poor working class neighborhood. In October, Lucien Camus is wounded and dies in Saint Brieuc.

1918 Camus enrolls in the local public school where he eventually meets his teacher, Louis Germain.

1923 Enters secondary school as a scholarship student. Meets Jean Grenier who will guide his reading and influence his thinking.

1930 First attack of tuberculosis.

1932 First published writing: four articles in the magazine Le Sud.

1933 Writing includes a poem: "Méditerranée". 
1934 Receives diplomas in Psychology and Classical Literature. Marries Simone Hie; the marriage ends less than two years later.

Writes "Les Voix du quartier pauvre", precursor to L'Envers et l'endroit".

1935 Joins the Communist Party.

1936 Receives "Diplôme d'études supérieures" from the University of Algers; his dissertation is entitled "Métaphysique chrétienne et néoplatonisme".

1937 Publishes L'Envers et l'endroit. Leaves the Communist Party.

1939 Publishes Noces.

1940 Exile in Paris. Marries Francine Faure, a mathematician from Oran.

1941 Returns to Oran to teach in a Jewish school.

1942 Publishes L'Etranger.

1943 Moves to German-occupied Paris. Works for Gallimard. Joins the resistance movement. Publishes Le Mythe de Sisyphe.

1944 Publishes two plays Caligula and Le Malentendu.

1945 Publishes Lettres à un ami allemand.

1947 Publishes La Peste.

1948 Staging of the play, L'Etat de siège.

1950 Publishes a play, Les Justes.

1951 Publishes L'Homme Révolté, a discussion of the ideology of revolution which is severely criticized by Jean-Paul Sartre. 
1954 Publishes L'Eté.

1956 Publishes La Chute.

1957 Publishes L'Exil et le royaume and Béflexions sur la peine capitale (the latter written jointly with Arthur Koestler).

1960 Camus is involved in an automobile accident in the south of France and dies January 4 at the age of 46.

1962 Gallimard publishes Camus' notebooks, Carnets 42).

1964 Gallimard publishes second volume of Carnets (1942-51).

1971 La Mort heureuse, a precursor to L'Etranger, is published posthumously.

1989 Last volume of Carnets is published.

1994 Le Premier Homme is published posthumously. 


\begin{abstract}
APPENDIX B
ABBREVIATIONS USED FOR CAMUS' WORKS IN THIS THESIS
\end{abstract}

E L'Envers et l'endroit
ETR L'Etranger
PR L'Exil et le revaume
LCE Lyrical and Critical Essays
$\mathrm{N}$
$\mathrm{P} \quad$ Noces
LPH Peste

